\title{
SOEP
}

SOEPpapers

on Multidisciplinary Panel Data Research

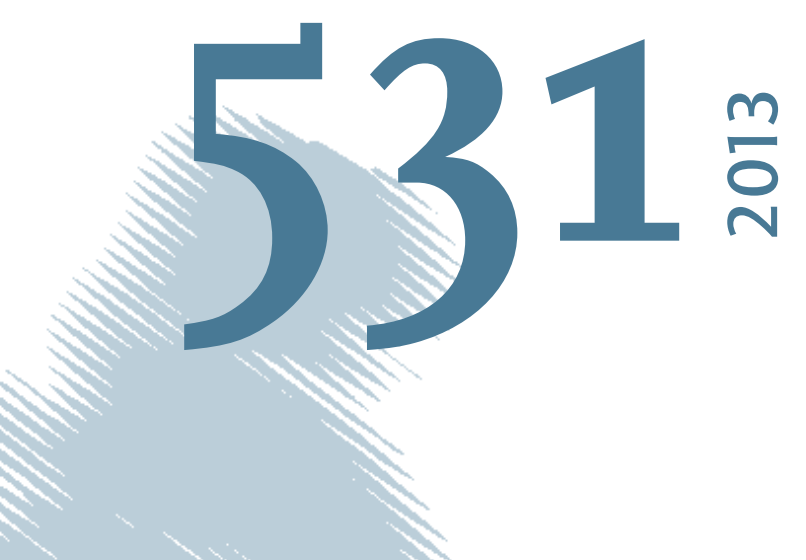

\section{The type to train? Impacts of personality characteristics on further training participation}




\section{SOEPpapers on Multidisciplinary Panel Data Research}

at DIW Berlin

This series presents research findings based either directly on data from the German SocioEconomic Panel Study (SOEP) or using SOEP data as part of an internationally comparable data set (e.g. CNEF, ECHP, LIS, LWS, CHER/PACO). SOEP is a truly multidisciplinary household panel study covering a wide range of social and behavioral sciences: economics, sociology, psychology, survey methodology, econometrics and applied statistics, educational science, political science, public health, behavioral genetics, demography, geography, and sport science.

The decision to publish a submission in SOEPpapers is made by a board of editors chosen by the DIW Berlin to represent the wide range of disciplines covered by SOEP. There is no external referee process and papers are either accepted or rejected without revision. Papers appear in this series as works in progress and may also appear elsewhere. They often represent preliminary studies and are circulated to encourage discussion. Citation of such a paper should account for its provisional character. A revised version may be requested from the author directly.

Any opinions expressed in this series are those of the author(s) and not those of DIW Berlin. Research disseminated by DIW Berlin may include views on public policy issues, but the institute itself takes no institutional policy positions.

The SOEPpapers are available at

http://www.diw.de/soeppapers

\section{Editors:}

Jürgen Schupp (Sociology, Vice Dean DIW Graduate Center)

Gert G. Wagner (Social Sciences)

Conchita D'Ambrosio (Public Economics)

Denis Gerstorf (Psychology, DIW Research Director)

Elke Holst (Gender Studies, DIW Research Director)

Frauke Kreuter (Survey Methodology, DIW Research Professor)

Martin Kroh (Political Science and Survey Methodology)

Frieder R. Lang (Psychology, DIW Research Professor)

Henning Lohmann (Sociology, DIW Research Professor)

Jörg-Peter Schräpler (Survey Methodology, DIW Research Professor)

Thomas Siedler (Empirical Economics)

C. Katharina Spieß (Empirical Economics and Educational Science)

ISSN: 1864-6689 (online)

German Socio-Economic Panel Study (SOEP)

DIW Berlin

Mohrenstrasse 58

10117 Berlin, Germany

Contact: Uta Rahmann | soeppapers@diw.de 


\title{
THE TYPE TO TRAIN?
}

\section{IMPACTS OF PERSONALITY CHARACTERISTICS ON FURTHER TRAINING PARTICIPATION.}

\author{
Version December 2012
}

\author{
Judith Offerhaus*
}

Personality traits drive behaviors and attitudes, and determine socio-economic life outcomes for individuals. This paper investigates the relationship of six personality traits, the Big Five and Locus of Control, to individual participation in employment-related further education and training (FET) in a longitudinal perspective. Initial research suggests that training is a crucial determinant of life chances. Taking this a step further, I ask what sorts of individual personality traits characterize the type to train. I attempt to answer this question using data from the German Socio-Economic Panel from the time period 2000-2008. Applying random-effects logistic regression models to 39,833 observations of 4,981 individuals over a period of nine years reveals that those who are open to new experiences and have high internal control beliefs are more likely to participate in FET, and this holds true for different model specifications. Contrary to the hypotheses, Agreeableness, Extraversion and Neuroticism do not impact FET, whereas the training effect of Conscientiousness is more complex. It shows that in addition to the classical determinants of FET such as educational level and occupational status, there are personality traits which characterize the type to train. Practical implications of this finding are discussed.

Keywords: Personality traits, Big Five, Locus of Control, Occupational training, Further education JEL Classification: I21, J24, M53

\footnotetext{
* Bremen International Graduate School of Social Sciences (BIGSSS), Jacobs University Bremen Campus Ring 1, South Hall, 28759 Bremen/Germany Email: jofferhaus@bigsss-bremen.de.
} 


\section{Introduction}

Common sense suggests that individuals with different personalities handle life situations differently, some better than others. Research confirms this, showing that personality determines educational performance, labor market participation, occupational attainment and overall happiness. Recently, economists in particular have incorporated personality variables into predictive models as useful controls of unobserved individual heterogeneity and to reduce unexplained variance (Heckman \& Rubinstein 2001; Heckman et al. 2006). By doing so, they challenge the mainstream view of the preeminence of cognitive abilities as individual determinants for outcomes in various life domains.

One strand of research where personality characteristics are not (yet) established is in the field of employment-related further education and training (FET). This is understood as another form of human capital investment (Becker 1962) undertaken in the labor market context after having left the traditional education system (Deutscher Bildungsrat 1970). Previous research on determinants of FET was predominantly driven by individual socio-demographic characteristics and institutional or structural labor market factors (Offerhaus et al. 2010). However, this paper adds personality characteristics. Based on other personality research, I derive hypotheses about the impact of the Big Five characteristics and Locus of Control on FET participation. I aim to investigate if there is a type to train, a set of personality characteristics which would matter most in regard to individual engagement in FET.

The first part of this paper describes these personality traits. This includes a thorough literature review leading to derived hypotheses. The next section discusses the dataset, and construction and validation of the measurements. Following that, the hypotheses are tested using randomeffects logistic panel regressions to predict participation in employment-related FET. Then several sensitivity analyses are implemented to check the robustness of these findings using additional control variables, and different model specifications and data configurations. Finally, the findings are discussed as first evidence of the type to train and in regard to practical applications in the training context. 


\section{Conceptual framework, previous research and new contributions}

Individual personality is a complex phenomenon. Countless concepts exist trying to capture its multifaceted nature. Generally speaking, "[ $p$ ]ersonality traits are the relatively enduring patterns of thoughts, feelings, and behaviors that reflect the tendency to respond in certain ways under certain circumstances." (Roberts 2009: 140; italics in the original). Two key concepts, namely the Big Five (also Five-Factor Model) and Locus of Control (LoC), are widely established as covering many personality-inherent complexities. Not only do these represent the broadest possible level of abstraction, they are also the most frequently used taxonomies in research dealing with the impact of personality differences on life outcomes.

\subsection{Conceptualization of personality traits}

\subsubsection{The Big Five}

This approach assumes that individual personality comprises of five different dimensions which in conjunction describe rather typical configurations of feeling, thinking and behaving (Costa \& McCrae 1994; Goldberg 1990).

Agreeableness. Agreeable individuals are tolerant, helpful, cooperative and altruistic in nature. They prefer compromise over conflict. Low scores are referred to as antagonism. Extraversion. Extraverts are active, action- and excitement-seeking, as well as sociable, but also dominant and urging compared to introverts with lower levels of social engagement and assertiveness. Conscientiousness. This refers to individual reliability, self-discipline, perseverance and achievementorientation as well as responsibility. Being conscientious implies being purposeful, strong-willed and deliberate. Openness to Experience. This is also referred to as intellect or culture, implying a sense of creativity and artistic-aesthetic appreciation. Other related characteristics are openmindedness, imagination, curiosity and adaptability. Neuroticism. This trait represents vulnerability to stress, level of anxiety and self-esteem, anger, or insecurity. Individuals with higher scores are emotionally more reactive and self-conscious. In reverse phrasing it is referred to as emotional stability. 


\subsubsection{Locus of Control}

Complementing, yet distinct from the Big Five, Locus of Control is another widely recognized and utilized measure in personality research; it is largely understood as predominantly learned behavior. According to Rotter (1966), LoC is either internal or external and refers to the individuals' perception of how actions relate to outcomes. Rotter (1975: 57) conceptualizes internality and externality of control beliefs as a continuum. Those with an external LoC believe that their lives are determined by others, luck or fate; in its most extreme form referred to as helplessness or fatalism. In contrast, an internal LoC stresses the importance of individual competencies, capabilities and choices in influencing outcomes. For more internal individuals, even a negative outcome is seen as a result of personal mistakes (internal attribution), whereas those with an external LoC believe that environmental factors beyond their control bring about outcomes (external attribution).

Locus of Control is not completely independent of the Big Five. A certain trait profile, namely higher scores on Openness, Conscientiousness and Extraversion, is associated with more internal control beliefs (Caliendo et al. 2010: 11), whereas Neuroticism is closely related to low selfesteem which, in turn, is linked to an external LoC (Bono \& Judge 2003).

\subsubsection{Stability and change in personality traits}

Costa and McCrae (1994) and McCrae and Costa (1999) initially argue that personality traits develop during childhood and early adolescence and remain stable after reaching maturity around age 30 (see also Caspi \& Roberts 1999), otherwise known as the plaster hypothesis. Later, the authors revised their strictly static understanding of the Big Five allowing for minor changes over the life course depending on contextual factors (Costa et al. 2000). For example, exogenous factors can affect thoughts, feelings and behaviors and induce momentary changes; and repeated exposure to such factors may lead to changes in personality (Roberts \& Jackson 2008: 1534). From a meta-analysis, Roberts et al. (2003) conclude that Conscientiousness and Agreeableness increase throughout adulthood, whereas Neuroticism decreases; this is understood as personality maturation in response to age-related norms and adult role-expectations (see also Caspi et al. 2005; Roberts et al. 2008; Specht et al. 2012). However, no overall change patterns were found for Extraversion and Openness. The malleability of personality characteristics is mostly pronounced 
at younger and older ages, but also influenced by the experience of critical life events such as child birth or unemployment (Roberts et al. 2006; Specht et al. 2011). Most studies report only mean-level and rank-order changes across different age groups, while research focusing on intra-individual changes in personality over the life course is scarce, and if available only span short time periods (Specht et al. 2012; Wortman et al. 2012). For LoC “[t]he average sense of control rises with education, earnings, income, employment, occupational status, job autonomy, and status of origin." (Mirowsky \& Ross 2007: 1343). Thus, "personality traits are never set in stone" (Wortman et al. 2012: 6); however, reported changes tend to be small and a complete personality reversal is unlikely.

\subsection{Literature review}

Prior research demonstrates that personality impacts multiple life course outcomes, especially happiness, occupational attainment, income, and educational performance. Yet, I show that until now a systematic integration of personality into FET research is lacking.

Life satisfaction, happiness and health. Individuals with low Neuroticism and high Extraversion (Headey 2008) or high Openness and Agreeableness (Trzcinsky \& Holst 2012) are generally more content. Moreover, Neuroticism is the most consistent predictor of relationship dissatisfaction and marriage dissolution (Roberts et al. 2007). Trzcinsky and Holst (2012) and Infurma et al. (2011) find that internal control beliefs are associated with higher life satisfaction and selfreported health. A meta-analysis by Roberts et al. (2007: 322-327) reveals that certain traits are related to longevity. Conscientiousness and Extraversion have protective effects, whereas higher Neuroticism leads to premature mortality.

Social mobility and status attainment. Evidence as early as Jencks et al. (1979) highlights the importance of personality and behavioral traits for labor market success. Jackson (2006) finds that personality characteristics measured in early adolescence are significant determinants of class destination in adulthood. Individuals with higher withdrawal scores (understood as lower Extraversion) are less likely to enter higher service class jobs and instead tend toward the working class. Bihagen et al. (2012) show evidence for the increasing importance of personality characteristics, compared to educational credentials, for membership in elite positions in Sweden over time. Cheng and Furnham (2012) find that Openness, Conscientiousness and Extraversion 
play a modest but important role in status attainment. Also Judge et al. (1999) show that Extraversion, Agreeableness and Conscientiousness positively, whereas Neuroticism negatively predict occupational status 50 years later with effect sizes comparable to educational and parental background (see also Roberts et al. 2007). Furthermore, Neuroticism has a small but significant impact of intergenerational class persistence (Blanden et al. 2007).

Income and earnings. In regard to monetary returns to personality, findings are mixed and ambiguous. Swedish registrar data show that personality variables, especially measures of social maturity (similar to Extraversion and Conscientiousness) and emotional stability (Neuroticism), explain a nontrivial part of intergenerational income correlations (Mood et al. 2012). For individual income, Mueller and Plug (2006) report a positive overall impact for the Big Five with an effect size normally found for cognitive abilities. For women, the wage level increases with Conscientiousness and Openness, whereas low Agreeableness for men is associated with a substantial earnings advantage. Heineck (2011) shows a positive relationship of Openness to wages, but a negative one for Agreeableness and Neuroticism. In contrast, Seibert and Kraimer (2001) report a wage penalty of Openness for both sexes and Braakmann (2009) finds a decrease in earnings associated with Agreeableness and Conscientiousness. Nyhus and Pons (2005) describe positive wage effects resulting from low Neuroticism for males and females, whereas Extraversion and Agreeableness significantly reduce female incomes. Individuals with external control beliefs experience a robust wage penalty (Groves 2005; Heineck \& Anger, 2010; Piatek \& Pinger 2010). For a Russian sample, Semykina and Linz (2007) report a monetary payoff of internal LoC, which is higher for females. Gender-specific differences in personality characteristics explain 7 to 15 percent of the gender wage-gap (Mueller \& Plug 2006; Semykina \& Linz 2007).

Unemployment duration and tenure. Uysal and Pohlmeier (2011) report longer unemployment duration for individuals with higher Neuroticism, whereas Conscientiousness increases the likelihood of employment. In contrast, Viinikainen and Kokko (2012) show that Extraversion and Agreeableness prolong the cumulative unemployment duration. Openness reduces both the spell frequency and overall time in unemployment. Agreeableness also has a negative impact on job tenure, whereas Conscientiousness and Openness increase job stability for females (Uysal \& Pohlmeier 2011). Effects regarding the Big Five differ for various industry sectors and levels of managerial responsibility, because individuals may self-select into occupations which match their trait profile and preferences (Uysal \& Pohlmeier 2011: 987; Borghans et al. 2008). Regard- 
less of sector, Braakmann (2009) finds that Conscientiousness associates with full-time employment positively, while Agreeableness and Neuroticism do negatively.

Labor force participation, job search and self-employment. For female work force participation, Wichert and Pohlmeier (2010) show a negative impact of Openness and Neuroticism, while high Extraversion and especially Conscientiousness enhance their labor market activities. Caliendo et al. (2010) show that internal LoC is associated with more intensified job search activities and a more positive outlook on re-employment prospects (also Uhlendorff 2004). In another study, Caliendo et al. (2011) find strong evidence for the impact of an internal LoC on the decision to enter and maintain self-employment (also Fritsch \& Rusakova 2010).

Educational attainment and skill acquisition. Protsch and Dieckhoff (2011) look the transition from school to vocational training in Germany and hypothesize differential effects of traits depending on individual educational background. They find respective support for Conscientiousness; highly conscientious students enter vocational training faster, but only if they have intermediate school certificates. Solga and Kohlrausch (2012) also find that low Conscientiousness and extreme scores on Agreeableness decrease training opportunities for low-achieving students. Studies as early as the 'Coleman Report' (1966) highlight the importance of an internal LoC for academic performance and educational achievement. Focusing on high school completion and college attendance, Coleman and DeLeire (2003) model how LoC influences educational decision-making. They conclude that control beliefs predominantly impact expectations about returns to schooling investments. Students with a more external LoC are more likely to assume that their behavior (graduation) will impact their labor market success less. Similarly, Prociuk and Breen (1975) show that students with internal control beliefs not only aim for higher levels of education but also perform better in an academic environment. Educational success, in reverse, might also lead to an increase in internal LoC over the life course (Mirowsky \& Ross 2007).

To summarize this large body of literature, personality traits have a considerable impact on life and labor market outcomes. However, results are mixed, sometimes contradictory. It also shows that personality characteristics do not display consistent effect patterns. There is no trait, except for internal LoC, which leads to consistent outcomes. 


\subsection{Personality traits and further training: research hypotheses}

To date, only Fouarge et al. (2012) investigate the impact of personality traits on attitudes towards FET and find that both Openness and an internal LoC are associated with a stronger willingness to engage in training. I know of no study probing the impact of personality on actual training participation, which so far is otherwise conceptualized as a function of demographic, socio-economic and structural-institutional variables. ${ }^{1}$ As shown in the previous section, personality traits are related to educational, occupational and earnings outcomes, which in turn are associated with FET participation (for example Hubert \& Wolf 2007; Konsortium Bildungsberichterstattung 2012; Kuwan et al. 2006; Offerhaus et al. 2010). Therefore, I hypothesize that FET is also predicted by personality traits. The Big Five and LoC can be seen as a set of productive skills which have an impact on the decision to train or to be trained. Individuals with certain trait profiles may be more likely to engage in training themselves as they are more motivated or interested. Also, employers might regard specific personality traits as a signal of high productivity and thus reward them with training opportunities.

As mentioned before, Conscientiousness is characteristic of people who are self-disciplined, industrious, focused and organized, i.e. display positive work habits. Also, conscientious individuals tend to show "constructive cognitive orientation" (Hartman \& Betz 2007: 148). Colquitt et al. (2000) report a positive association of Conscientiousness to training and learning motivation. Thus, more conscientious individuals should be more likely to seek improvements in their labor market situations through deliberate FET engagement. Job performance research shows, when assessed by the employer, more conscientious individuals tend to be more committed and fulfill tasks better compared to their coworkers (Barrick \& Mount 1991); presumably this perception leads employers to offer FET to hard-working and dutiful individuals.

In the context of work, Agreeableness could be interpreted as an advantage in team-work situations and conflict avoidance. Also, agreeable individuals are less assertive; therefore they might not be as successful in job-related negotiations, when for example requesting FET courses or related financial support. Agreeableness could also lead individuals to hold more egalitarian attitudes; they might not want to take opportunities from others, and therefore are more compla-

${ }^{1}$ After finishing this analysis, I came across a working paper looking at the impact of the Big Five and Locus of Control on participation in FET (Görlitz \& Tamm 2012). The authors find that, when controlling for tasks performed at work and job complexity, traits are generally unrelated to training, except Openness, which is a negative predictor of on-the-job training. But it remains rather unclear how they constructed their measurements or how they specified their models, thus I will refrain from using this working paper as concrete evidence on the subject. 
cent with respect to their career prospects. Both these arguments indicate that higher Agreeableness should associate with lower training rates.

Individuals scoring higher on Extraversion are ambitious, outgoing, pro-social and communicative. Moreover, Extraversion is a strong predictor for leadership responsibilities and behaviors (Judge et al. 1999). Thus employers may provide more training opportunities to those with high Extraversion as a preparation for career advancement to managerial positions. Similarly, Openness is associated with intellectual curiosity. More open individuals tend to be particularly eager to improve their knowledge and skills or search for new learning opportunities (Major et al. 2006), which, like Extraversion, should increase their FET engagements.

Research shows that Neuroticism hinders effective career management (Ng et al. 2005: 373) and is associated with low career self-efficacy (Hartman \& Betz 2007). It also leads to emotional instability and stress, especially in the work context. Neurotic individuals might avoid the extra demands of FET and supervisors may have less confidence in these individuals to succeed in training. Thus, Neuroticism should reduce FET prospects.

Individuals with a more internal Locus of Control show greater initiative and willingness to contribute to outcomes, like career progression or job change. In contrast, an external LoC is linked to individuals' perceptions of being incapable of improving or changing work conditions, for instance. Ng et al. (2006: 1060) describe individuals with internal control beliefs as "choice making agents" who have more confidence in their abilities and higher intrinsic motivation. Additionally, an internal LoC is associated with setting more demanding goals (Bandura \& Wood 1989). FET activities could be understood as an additional challenge in balancing normal work routines and possible family obligations, not only in regard to time-constraints but also to financial impediments. Thus, internal control beliefs should increase FET frequency.

The hypothesized effects derived from the preceding discussion are summarized in Table 1.

Table 1 Summary of research hypotheses

\begin{tabular}{l|l}
\hline Impact on FET participation & Personality traits \\
\hline Positive & Extraversion, Openness, Conscientiousness, Internal Locus of Control \\
Negative & Agreeableness, Neuroticism \\
\hline
\end{tabular}




\section{Data, measurements and methods}

\subsection{Data: The German Socio-Economic Panel (SOEPv27)}

The SOEP is a longitudinal survey, started in 1984 with a representative random sample of the West German population. Later, the sampling framework was extended to cover East Germany and non-native individuals. In order to maintain a high number of respondents, a refresher sample was introduced in 2000. Up to its most recent wave, the SOEP comprises information on nearly 11,000 private households and 23,000 individuals (also Wagner et al. 2007). The annual questionnaire covers topics ranging from educational attainment, life satisfaction, and health to housing and cultural activities as well as psychologically relevant information. Since the mid1990s, the SOEP also provides a LoC measure; however the early versions differ either in question wording or scaling compared to recent waves (2005 and 2010). For the first time in 2005 and repeatedly in 2009, the SOEP also featured a scale of the Big Five personality traits.

In this paper I use data from 2000 through 2008. Individuals, who have missing information on personality variables, the detailed FET modules or are non-respondents for more than one year, are excluded from the sample. For my analysis, the nine-year observation window covers a period long enough to include substantial information on employment biographies and other life course events. However, I exclude individuals aged 65 and older in 2008, thus restricting my sample to the working age population $(N=4,981)$.

\subsection{Variables and measurements}

\subsubsection{Dependent variable: further training participation}

The SOEP regularly features detailed modules on FET, namely in the years 2000, 2004, and 2008. ${ }^{2}$ These questions address the working age population under 65 and target activities in the three years prior to the survey (Figure 1).

\footnotetext{
2 The other two years, 1989 and 1993, are not considered.
} 
Figure 1 Survey structure regarding further training questions in the SOEP

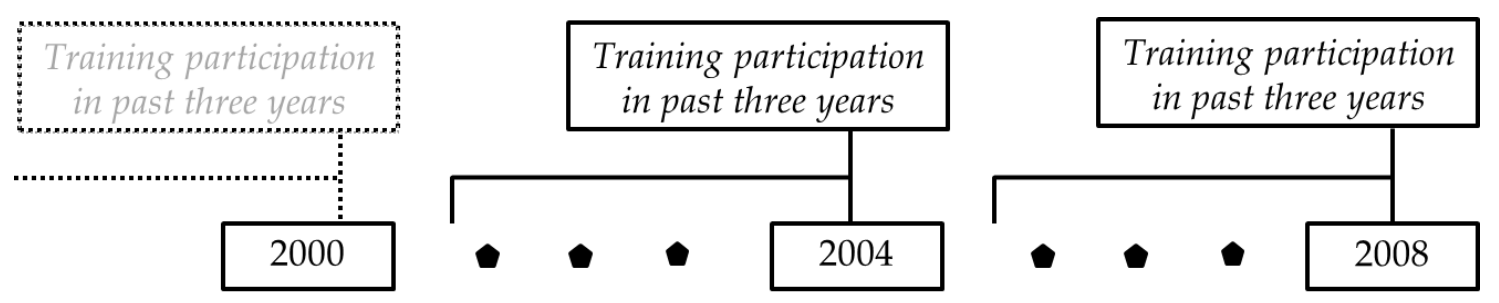

The main question asks: There are different opportunities available if one wants to educate himself further. Think back on the last three years. Have you in that time period done any of the following to further your professional education? Although the training question lists multiple FET types, I only focus on participation in work-related, professionally organized training courses. For those who report training participation within the past three years, the SOEP provides information on up to three of the most recent training courses, for example regarding financing structure, knowledge transfer, and course duration. In order to improve the accuracy of my dependent variable, I use the latter information to construct a measure which indicates yearly training participation or, to be more precise, the years when respondents actually started their courses. As respondents can only provide comprehensive information on a maximum of three courses, and often report participation either in multiple courses in one year or more than three courses within the past three years, course participation is distributed unevenly across the years sampled. Participation rates peak in the year prior to the detailed training module and then decline considerably over the next years, most likely a recency effect (Greene 1986) (see Table 2).

In order to correct some of the measurement error associated to FET and to complement my yearly training measure, I use two additional annual questions regarding participation. (1) The calendar (artkalen-file) provides month-by-month data on various employment states and characteristics and also includes information on further training, retraining or further professional education which I aggregated into yearly information. (2) Are you currently in some sort of education? In other words, do you attend a school or institution of higher education, are you engaged in an apprenticeship or are you participating in further education or training? With the respective answer categories of interest: Professional or vocational retraining; Further education in your profession; Professional rehabilitation; Further education in politics or general. These questions are only utilized if individuals 
reported that they actually participated in FET courses but did not provide additional information. ${ }^{3}$

Table 2 Frequencies of further training incidents from different SOEP questions

\begin{tabular}{l|c|cccc|cccc}
\hline & $\mathbf{2 0 0 0}$ & $\mathbf{2 0 0 1}$ & $\mathbf{2 0 0 2}$ & $\mathbf{2 0 0 3}$ & $\mathbf{2 0 0 4}$ & $\mathbf{2 0 0 5}$ & $\mathbf{2 0 0 6}$ & $\mathbf{2 0 0 7}$ & $\mathbf{2 0 0 8}$ \\
\hline Special further training modules & 27.1 & & & & 26.4 & & & & 26.1 \\
Information on individual courses & 3.3 & 6.0 & 12.1 & 18.8 & 3.5 & 4.8 & 11.3 & 20.1 & 7.4 \\
Calendar information & 3.5 & 3.7 & 3.6 & 3.7 & 3.2 & 2.7 & 2.2 & 2.1 & 2.1 \\
Currently in further training & 2.5 & 2.7 & 2.9 & 2.1 & 1.9 & 1.6 & 1.0 & 1.2 & 1.2 \\
Combined information & $\mathbf{6 . 7}$ & $\mathbf{8 . 0}$ & $\mathbf{1 3 . 6}$ & $\mathbf{2 0 . 1}$ & $\mathbf{6 . 2}$ & $\mathbf{6 . 9}$ & $\mathbf{1 2 . 5}$ & $\mathbf{2 1 . 4}$ & $\mathbf{8 . 9}$ \\
\hline
\end{tabular}

SOEP 2000-2008, own calculations

Table 2 gives an overview of the different FET participation rates taken from the various SOEP questions. On average, around one-third of the sample participated in at least one FET course between 2000 and 2008. As already mentioned, training incidences peak in the years after the detailed FET modules (2007 and 2003; 1999 not included in the sample) and decline till the end of each observation window. As there is no feasible way to avoid it, I may underestimate the number of years where individuals engage in training.

It is rather difficult to construct a coherent measure of training participation, yet I argue that my measurement is quite comprehensive as it combines all FET information available in the SOEP and is a large improvement over simply using the FET modules in pooled analyses.

\subsubsection{Independent variables: personality traits}

The Big Five. A robust and reliable short item battery, the BFI-S, was developed to efficiently depict the five personality components (Dehne \& Schupp 2007; Gerlitz \& Schupp 2005). Each of the Big Five characteristics is represented by three heterogeneous items, some in reverse coding (see Table 3), though not clustered together in the questionnaires. Gerlitz and Schupp (2005: 22) show that both the convergent validity and the internal consistency measured by the inter-item correlation of this short inventory are satisfactory and comparable to the normally used longer version BFI-25. Cronbach's Alpha increases with the number of items used (Cortina

\footnotetext{
${ }^{3}$ A few respondents (average 1 percent yearly) were inconsistent in reporting non-participation in the training module, but provide information on participation in some sort of training in either the monthly calendar or the question whether they are currently in education. Those cases are not considered in the construction of my dependent variable as I have to assume that their FET courses are not necessarily employment-related or professionally oriented.
} 
1993), thus it is not surprising that the respective SOEP values (based on three items each) are lower compared to longer versions of the inventory (like the NEO PI-R with 240 items altogether or the NEO-FFI with 12 items per trait). Compared to Gerlitz and Schupp's (2005: 21) results for the BFI-S, I find a slightly larger average level of reliability (Table 5) for my sample with standardized Alphas ranging from 0.59 (Agreeableness) to 0.71 (Extraversion).

Table 3 Big Five items and respective stability between 2005 and 2009, in percent

\begin{tabular}{|c|c|c|}
\hline $\begin{array}{l}\text { I see myself as someone who ... } \\
(1=\text { does not apply to me; to } 7 \text { = fully applies to me })\end{array}$ & $\begin{array}{c}\text { 1-point } \\
\text { difference }\end{array}$ & $\begin{array}{l}\text { 2-point } \\
\text { difference }\end{array}$ \\
\hline \multicolumn{3}{|l|}{ Conscientiousness } \\
\hline (thorough) does a thorough job & 89.9 & 96.8 \\
\hline (effective) does things effectively and efficiently & 84.9 & 95.4 \\
\hline$(l a z y)$ tends to by lazy (reversed) ${ }^{\mathrm{a}}$ & 76.2 & 87.6 \\
\hline \multicolumn{3}{|l|}{ Agreeableness } \\
\hline$(\text { rude) is sometimes rude to others (reversed })^{\mathrm{a}}$ & 68.5 & 85.6 \\
\hline (forgive) has a forgiving nature & 76.7 & 91.3 \\
\hline (kind) is considerate and kind to others & 83.4 & 95.5 \\
\hline \multicolumn{3}{|l|}{ Extraversion } \\
\hline (talk) is communicative, talkative & 81.0 & 94.5 \\
\hline$\left(\right.$ reserved) is reserved (reversed) ${ }^{a}$ & 67.3 & 86.8 \\
\hline (social) is outgoing, sociable & 77.7 & 93.1 \\
\hline \multicolumn{3}{|l|}{ Openness to Experience } \\
\hline (image) has an active imagination & 72.6 & 89.4 \\
\hline (original) is original, comes up with new ideas & 75.6 & 91.8 \\
\hline (art) values artistic experiences & 66.6 & 85.2 \\
\hline \multicolumn{3}{|l|}{ Neuroticism } \\
\hline (worry) worries a lot & 68.0 & 85.8 \\
\hline (nervous) gets nervous easily & 66.7 & 85.5 \\
\hline (stress) is relaxed, handles stress well (reversed) ${ }^{\mathrm{a}}$ & 71.7 & 89.2 \\
\hline
\end{tabular}

a Original coding reversed for consistency with other items.

SOEP 2005 and 2009, own calculations

Big Five questions were first implemented in 2005 and re-occurred in 2009, after the period investigated herein. This offers the advantage of repeated measurements allowing me to actually test for intra-individual trait stability instead of simply assuming it. The sample means (not shown here) for the individual Big Five items change only marginally between the two waves (on average \pm 0.1 ). This stability goes in line with previous conceptual arguments (Costa \& McCrae 1994; Goldberg 1990). 
To get a better grasp of actual trait stability, I subtract the average score for each Big Five item of the two respective years. With a rather conservative stability measure, at least two-thirds of the respondents reported their traits in 2009 within 1-point (in either direction of a 7-point scale) of the same trait item in 2005 (see Table 3). Around 85 to almost 97 percent (on average 90 percent) answer the respective items in 2005 and 2009 similarly when allowing a 2-point-difference. This does not appear to represent a substantial personality change, yet it is unclear if the intraindividual item variability is attributable to measurement error or represents a personality significant change.

Locus of Control. The ten LoC items in the SOEP (2005 and 2010) are based on a scale by Krampen (1981), and listed in Table 4.

Table 4 Locus of Control items and respective stability between 2005 and 2010, in percent

\begin{tabular}{|c|c|c|}
\hline $\begin{array}{l}\text { The following statements apply to different attitudes towards life and the future. To what } \\
\text { degree do you personally agree with the following statements? } \\
\text { (1 = disagree completely; to } 7 \text { = agree completely) }\end{array}$ & $\begin{array}{c}\text { 1-point } \\
\text { difference }\end{array}$ & $\begin{array}{l}\text { 2-point } \\
\text { difference }\end{array}$ \\
\hline I1. How my life goes depends on me. & 74.9 & 90.8 \\
\hline I2. Compared to other people, I have not achieved what I deserve. & 61.6 & 79.3 \\
\hline I3. What a person achieves in life is above all a question of fate or luck. & 65.7 & 84.7 \\
\hline I4. If a person is socially or politically active, he/she can have an effect on social conditions. & 61.2 & 82.8 \\
\hline I5. I frequently have the experience that other people have a controlling influence over my life. & 63.4 & 82.3 \\
\hline I6. One has to work hard in order to succeed. & 82.9 & 94.5 \\
\hline I7. If I run up against difficulties in life, I often doubt my own abilities. & 66.5 & 83.9 \\
\hline I8. The opportunities that I have in life are determined by the social conditions. & 64.1 & 86.0 \\
\hline I9. Inborn abilities are more important than any efforts one can make. & 69.3 & 88.7 \\
\hline I10. I have little control over the things that happen in my life. & 70.8 & 86.8 \\
\hline
\end{tabular}

SOEP 2005 and 2010, own calculations

Compared to the Big Five, the usage of these items is more controversial. One strand of research considers internal and external control beliefs as two separate, independent factors (Caliendo et al. 2009; Rammstedt 2007), whereas the majority in the literature regards both as opposite ends of a continuum (Headey 2008; Piatek \& Pinger 2010; Trzcinski \& Holst 2010). Yet, within this research tradition the actual item usage is inconsistent and partially intransparent (as Dittmann \& Goebel 2010; Headey 2008), often not clearly based on rigorous statistical analyses. Yet, it does not seem that there is a precedent. I aim to develop a robust measurement using theoretically and statistically driven justifications for constructing LoC on a continuum. 
Following the same procedure as with the Big Five, I test for intra-individual stability in the control belief items between 2005 and 2010 (Table 4). Intra-item consistency within a 1-point difference ranges from 61.2 (I4) to 83.0 percent (I6) and allowing for variation by maximum 2-points, stability lies between 79.3 (I2) and 94.5 percent (I6) with an average of 86.1 percent, which indicates reasonable reliability.

Scale construction and validation. In order to formally address the reliability of all personality measures, I conduct a principal components factor analysis with orthogonal varimax rotation on the 15 Big Five items along with all 10 items used to measure LoC. Table 5 reports the rotated factor loadings and shows six clearly distinguishable factors within these 25 items (correlations in Appendix Table 9).

Table 5 Factor analysis of personality trait items

\begin{tabular}{|c|c|c|c|c|c|c|c|c|c|c|c|c|c|c|c|c|c|c|c|c|c|c|c|c|c|}
\hline & \multicolumn{3}{|c|}{ Consc } & \multicolumn{3}{|c|}{ Agree } & \multicolumn{3}{|c|}{ Extra } & \multicolumn{3}{|c|}{ Open } & \multicolumn{3}{|c|}{ Neuro } & \multicolumn{10}{|c|}{ LoC (external-internal) } \\
\hline & 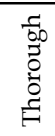 & 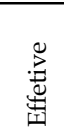 & 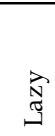 & $\frac{\ddot{D}}{2}$ & 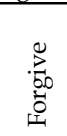 & $\underset{\Xi}{\Xi}$ & 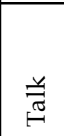 & 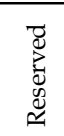 & $\begin{array}{l}\text {.ే } \\
\text { ర్ } \\
\text { ஸे }\end{array}$ & 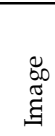 & 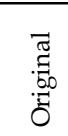 & 荤 & $\begin{array}{l}\overrightarrow{0} \\
3 \\
3\end{array}$ & $\begin{array}{l}0 \\
0 \\
0 \\
Z \\
Z\end{array}$ & $\begin{array}{l}\infty \\
\dot{D} \\
\stackrel{ \pm}{ \pm}\end{array}$ & 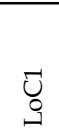 & త్త & $\underset{0}{త}$ & 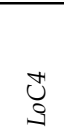 & לֶ, & $\underbrace{0}_{0}$ & $\underset{0}{0}$ & ְִ & త్త & 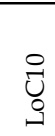 \\
\hline Consc & .81 & .74 & .62 & .03 & .08 & .27 & .19 & -.12 & .10 & .07 & .29 & .06 & .20 & -.09 & -.17 & -.08 & -.03 & .02 & .26 & .04 & -.03 & .25 & .04 & -.08 & .15 \\
\hline Agree & .08 & .10 & .27 & .77 & .59 & .74 & .16 & -.21 & .14 & .04 & -.18 & .17 & .08 & -.07 & -.13 & .02 & .17 & -.04 & -.04 & .09 & -.09 & -.02 & -.09 & -.01 & .06 \\
\hline Extra & .01 & .09 & .10 & -.12 & .21 & .12 & .74 & .75 & .76 & .33 & .38 & .10 & .01 & -.09 & -.07 & -.06 & -.02 & .03 & .22 & .08 & -.10 & .19 & -.02 & -.06 & .12 \\
\hline Open & .09 & .19 & -.19 & -.09 & .06 & .19 & .25 & -.09 & .26 & .66 & .62 & .73 & .01 & .09 & -.19 & -.11 & .09 & .05 & -.50 & -.08 & .09 & -.04 & -.03 & -.02 & .03 \\
\hline Neuro & -.02 & -.10 & -.02 & -.15 & .02 & .04 & -.01 & -.16 & -.03 & .03 & -.10 & .07 & .71 & .81 & .71 & .10 & -.12 & .02 & .15 & -.15 & -.10 & -.45 & -.11 & -.01 & -10 \\
\hline LoC & .06 & .12 & .02 & .03 & .07 & .07 & .04 & .10 & .06 & -.01 & .04 & .04 & -.22 & -.07 & -.03 & .50 & -.65 & -.66 & .01 & -.70 & -.70 & -.46 & -.53 & -.18 & -.75 \\
\hline Eigenvalue & & 2.0 & & & 1.3 & & & 2.7 & & & 1.4 & & & 1.5 & & & & & & 4. & 4 & & & & \\
\hline Alpha & & 0.68 & & & 0.59 & & & 0.72 & & & 0.68 & & & 0.66 & & & & & & 0.6 & & & & & \\
\hline
\end{tabular}

a Item 4 dropped from the LoC factor

SOEP 2005, 2009 and 2010, own calculations

In regard to the Big Five, factor loadings shown in the shaded cells are strong with values ranging from 0.62 through 0.81 , while cross-loadings are generally low with only few approaching a value of roughly 0.2 or 0.3 . Standardized Cronbach's Alphas demonstrate scale reliability ranging from 0.59 to 0.71 . Statistically speaking, the LoC factor is more problematic. Item LoC4 is particularly unsuited to capturing the latent factor and has cross-loading problems, and therefore is dropped from the analysis. Without this item, the remaining LoC scale has the highest Eigenvalue of all traits and demonstrates satisfactory scale reliability with an Alpha of 0.68. Therefore, there is enough statistical evidence coupled with sound theoretical reasoning to create a continuous latent LoC variable from these items. However, certain items (LoC1 and LoC5) are stronger predictors of control beliefs than others with rather low loadings (LoC6 and LoC9). 
In order to construct my latent personality variables, I average the scores for each item between the two years of measurement. The mean is the best possible estimation of each respondent's true score as it reduces potential random error between the two time points. I then utilize linear predictive factor scoring to generate the six latent personality characteristics; all traits are standardized to a mean of 0 and SD of 1, where positive scores indicate higher levels for the Big Five and a more internal LoC. Overall, all six measures retain a moderate degree of independence, which suggests that the latent personality traits, besides from being measured well, are relatively unique in terms of covariance with each other. As this research is somewhat exploratory I do not restrict the correlations among the Big Five and LoC to zero, especially as findings indicate certain trait interrelations (see section 2.1).

Autocorrelations of both the single items and the respective traits between the two observations suggest that the measurements are stable over time (Appendix Table 10). In order to statistically substantiate my stability claim, I draw upon the Reliable Change Index (RCI) used in clinical psychology (Jacobson \& Truax 1991). The RCI assess "whether the change in a personality trait is of sufficient magnitude to be confident that the change is beyond what could be attributed to a measurement error" (Viinikainen \& Kokko 2012: 18). Table 6 reports the individual level stability and change in the personality characteristics measured by the RCI.

Table 6 Reliable Change Index for personality stability and change, in percent

\begin{tabular}{l|ccc}
\hline & Stability & Increase & Decrease \\
\hline Conscientiousness & 96.3 & 1.6 & 2.1 \\
Agreeableness & 97.7 & 1.9 & 1.9 \\
Extraversion & 96.2 & 1.4 & 1.9 \\
Openness & 96.7 & 1.8 & 1.6 \\
Neuroticism & 96.6 & 1.8 & 1.6 \\
Locus of Control & 97.2 & 1.6 & 1.1 \\
\hline
\end{tabular}

SOEP 2005, 2009 and 2010, own calculations

It shows that the latent traits are remarkably stable with only 2 to 4 percent of individuals showing significant differences from 2005 to 2009/2010.4 This also legitimizes the usage of the personality measures I constructed by averaging each item's scores from the two years and then

\footnotetext{
4 To address the problem of reverse causality, I check whether trait scores change after FET participation. T-tests reveal no difference in participation for individuals with stable personalities and those reporting a change beyond measurement error; thus, FET seems to be a relatively insignificant life event which does not induce personality change.
} 
using predicted factor scoring. However, this high degree of trait stability over a short observation period does not imply general stability over the life course (ecological fallacy). Yet, using the RCI instead of just conveniently assuming that personality characteristics are exogenous variables which are formed before labor market entry or FET participation, provides robust evidence of stability in my observation period, which is critical for making causality arguments.

Control variables. I include various measures to ensure that results in regard to personality are not biased by demographic or structural-institutional factors. For demographics, female distinguishes men $(=0)$ from women $(=1)$, marital status denotes the relationship status (single, married or divorced/separated), children captures any children under 16 living in the household, age is measured in years and $a g e^{2}$ allows for curvilinearities. West captures the geographical location and migration indicates a migration background, i.e., if the respondent or his/her parents were not born in Germany or hold a nationality other than German. Educational attainment is measured with the CASMIN classification (high, intermediate and low), occupational status is EGP (service, intermediate, working, routine working class, self-employed); EGP is also used to account for current unemployment. Labor market participation is captured by yearly employmentrelated variables as full-or part-time and type of work contract (permanent vs. temporary or shortterm). Finally I control whether the individual is working in the public sector. Yearly dummies also account for measurement error which varies annually because of the nature of the dependent variable. For a summary of measurements, descriptive statistics and correlations refer to Appendix Table 11 and Table 12. As sensitivity controls I measure the institutional structure of the labor market and workplace environment by industry sector (1-digit NACE system) and company size.

\subsubsection{Method}

I use random-effects logistic panel regressions to account for factors which may lead to unobserved heterogeneity over the nine-year observation window (Frees 2004; Wooldridge 2010). I choose random- over fixed-effects modeling because it allows modeling of time-invariant independent variables such as biological sex, migration background and, most importantly, personality traits. Also, my hypotheses predict that personality traits should have a general impact on the working age population's training participation, net of the effect of demographics and variables related to socio-economic status and employment, and my models test for this with the in- 
clusion of these as controls. For ease of interpretation, I calculate the odds-ratios for all independent variables, and discuss how personality traits thus change the likelihood of FET participation.

\section{Results}

Figure 2 illustrates the differences in personality for training participants and non-participants. It graphs the kernel density estimates and visually compares the different trait profiles. Individuals participating at least in one training event between 2000 and 2008 differ significantly in Extraversion, Openness, Neuroticism, and LoC compared to those who did not report training. In line with my hypotheses, participants are less neurotic, more extraverted and open, and have higher internal control beliefs. LoC differences are most pronounced, whereas respondents are similar in regard to Conscientiousness and Agreeableness.

Figure 2 Distribution (kernel density) and means of personality traits by participation status
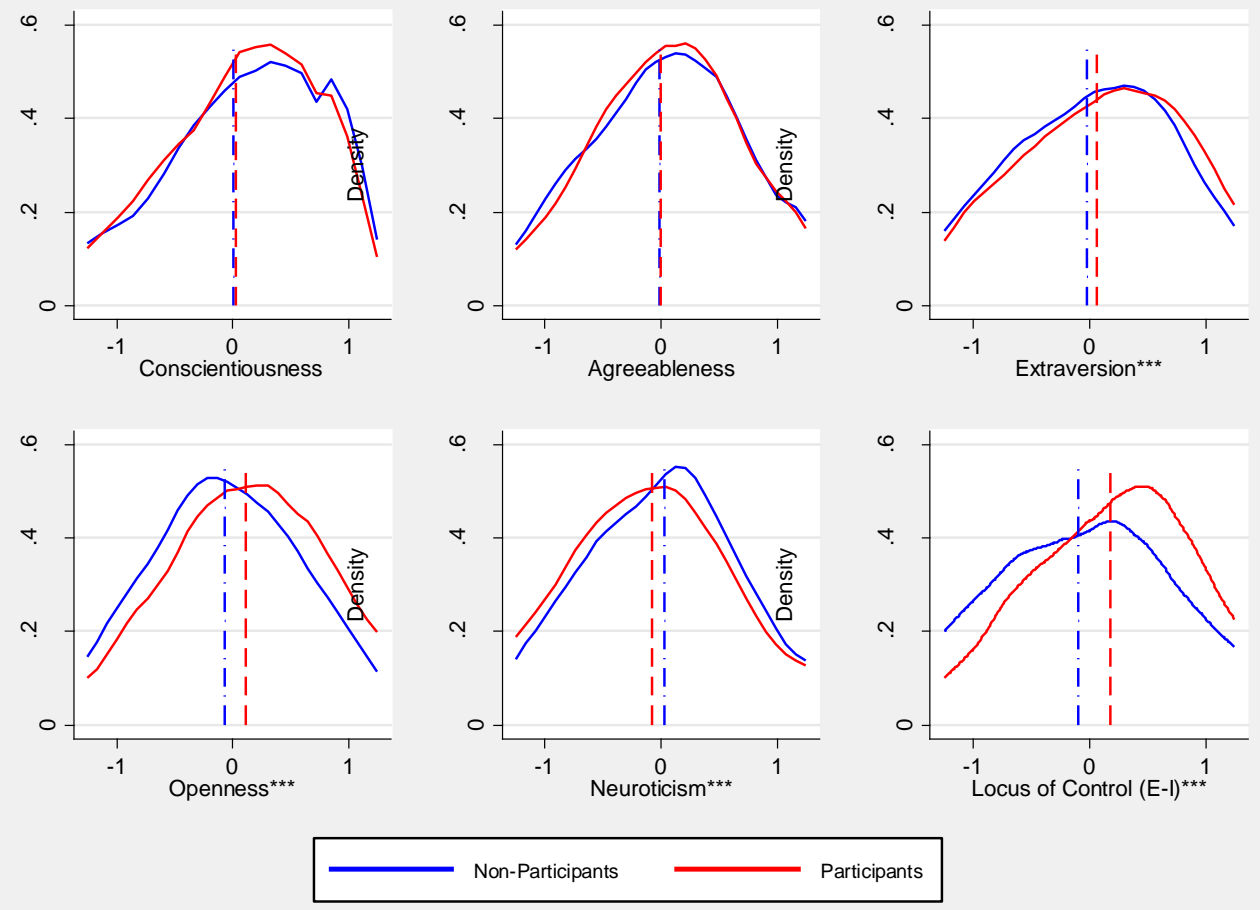

Differences significant at *** $0.001 * * 0.01 * 0.05$

SOEP 2000-20010, own calculations

I first run my regression model including only the Big Five and LoC (Table 7). Except Conscientiousness and Extraversion, all traits have the hypothesized relationship with FET; high Agreea- 
bleness scores appear to reduce FET likelihood, whereas higher Openness and more internal control beliefs increase it, and have by far the most substantial coefficient sizes. Unexpectedly, more conscientious individuals participate significantly less. Also, there is no significant difference between introverts and extroverts or emotionally stable and neurotic individuals.

Table 7 Impact of personality traits on further training, random-effects logistic panel regression

\begin{tabular}{l|ccc}
\hline & Coeffs. & S.E. & Odds ratio \\
\hline Conscientiousness & $-0.19^{* * *}$ & 0.05 & $0.83^{* * *}$ \\
Agreeableness & $-0.12^{*}$ & 0.06 & $0.88^{*}$ \\
Extraversion & -0.06 & 0.05 & $n s$ \\
Openness & $0.49^{* * *}$ & 0.06 & $1.64^{* * *}$ \\
Neuroticism & -0.08 & 0.05 & $n s$ \\
Locus of Control & $0.52^{* * *}$ & 0.05 & $1.68^{* * *}$ \\
\hline Constant & $-3.84^{* * *}$ & 0.05 & $0.02^{* * *}$ \\
N individuals & & 4,981 & \\
N observations & & 39,833 & \\
AIC & & 25,460 & \\
Marginal probability & & 0.11 & \\
\hline
\end{tabular}

Significant at ${ }^{* * *} 0.001 * * 0.01 * 0.05$

Model controls for yearly dummy variables

SOEP 2000-2010, own calculations

The full analysis proceeds in two stages. First, Model I (first column, Table 8) includes demographic, socio-economic, and other controls regarding employment specifics to establish a baseline model. Results indicate the 'usual suspects' in regard to training participation (Offerhaus et al. 2010) with level of education and occupational status being the strongest determinants. Also, native-born Germans and public sector employees are more likely to train. Women have on average lower participation rates; however, this effect is insignificant. Age has a curvilinear effect that is strongest in early labor market participation and declines later as seen in the quadratic term. Generally speaking, for ease of interpretation, increases and decreases in odds must be viewed in context of the overall odds of participation for an 'average' individual in the sample; these are captured as the marginal probability (lower panel of the table), which would be 10 percent in any given year. For example interpreting the impact of civil service employment, a change in odds of 1.64 or a 64 percent increase would mean that the likelihood of participation for this otherwise 'average' person would improve from 10 to 16.4 percent (i.e. 10.0 times 1.64). All odds-ratios may be interpreted in this way by comparison to the marginal probability. 
Table 8 Random-effects logistic panel regression predicting further training participation

\begin{tabular}{|c|c|c|c|c|c|c|}
\hline & \multicolumn{3}{|c|}{ Model I without personality traits } & \multicolumn{3}{|c|}{ Model II with personality traits } \\
\hline & Coeffs. & S.E. & Odds ratio & Coeffs. & S.E. & Odds ratio \\
\hline Female & -0.15 & 0.08 & ns & -0.14 & 0.08 & ns \\
\hline Age & $0.07^{* *}$ & 0.03 & $1.08^{* *}$ & $0.08^{* *}$ & 0.03 & $1.09^{* *}$ \\
\hline Age $^{2}$ & $-0.00^{* * *}$ & 0.00 & $1.00^{* * *}$ & $-0.00^{* * *}$ & 0.00 & $1.00^{* * *}$ \\
\hline Married & 0.09 & 0.09 & $n s$ & 0.09 & 0.09 & $n s$ \\
\hline Divorced & 0.17 & 0.12 & $n s$ & 0.15 & 0.12 & ns \\
\hline Children under 16 & 0.01 & 0.06 & $n s$ & 0.00 & 0.06 & ns \\
\hline West & 0.12 & 0.08 & $n s$ & 0.06 & 0.08 & $n s$ \\
\hline Migration & $-0.77^{* * *}$ & 0.11 & $0.47^{* * *}$ & $-0.71^{\star * *}$ & 0.11 & $0.49^{* * *}$ \\
\hline Full-time employment & 0.25 & 0.17 & $n s$ & 0.21 & 0.17 & $n s$ \\
\hline Part-time employment & -0.07 & 0.18 & $n s$ & -0.09 & 0.18 & $n s$ \\
\hline Education intermediate & $0.78^{* * *}$ & 0.09 & $2.18^{* * *}$ & $0.70^{* * *}$ & 0.09 & $2.02^{* * *}$ \\
\hline Education high & $1.51^{* * *}$ & 0.11 & $4.54^{* * *}$ & $1.36^{* * *}$ & 0.11 & $3.89^{* * *}$ \\
\hline EGP Missing & $0.53^{*}$ & 0.24 & $1.69 *$ & $0.48^{*}$ & 0.24 & ns \\
\hline EGP Unemployed & $0.76^{* * *}$ & 0.21 & $2.13^{* * *}$ & $0.76^{* * *}$ & 0.21 & $2.13^{* * *}$ \\
\hline EGP Service class & $0.95^{* * *}$ & 0.10 & $2.60^{* * *}$ & $0.89^{* * *}$ & 0.10 & $2.44^{* * *}$ \\
\hline EGP Intermediate & $1.03^{* * *}$ & 0.12 & $2.81^{* * *}$ & $1.00^{* * *}$ & 0.12 & $2.72^{* * *}$ \\
\hline EGP Working class & $0.47^{* * *}$ & 0.10 & $1.60^{* * *}$ & $0.45^{* * *}$ & 0.10 & $1.57^{* * *}$ \\
\hline EGP Self-employed & $0.53^{* * *}$ & 0.15 & $1.70^{* * *}$ & $0.43^{* *}$ & 0.15 & $1.54^{* *}$ \\
\hline Permanent contract & $0.28^{* *}$ & 0.09 & $1.32^{* *}$ & $0.28^{* *}$ & 0.09 & $1.32^{* *}$ \\
\hline Temporary contract & 0.10 & 0.09 & $n s$ & 0.10 & 0.09 & $n s$ \\
\hline Public sector & $0.50^{* * *}$ & 0.07 & $1.64^{* * *}$ & $0.50^{* * *}$ & 0.07 & $1.64^{* * *}$ \\
\hline Conscientiousness & & & & -0.03 & 0.05 & $n s$ \\
\hline Agreeableness & & & & -0.08 & 0.05 & ns \\
\hline Extraversion & & & & 0.02 & 0.05 & $n s$ \\
\hline Openness & & & & $0.29^{* * *}$ & 0.05 & $1.33^{* * *}$ \\
\hline Neuroticism & & & & -0.02 & 0.05 & $n s$ \\
\hline Locus of Control & & & & $0.30^{* * *}$ & 0.05 & $1.35^{* * *}$ \\
\hline Constant & $-6.11^{* * *}$ & 0.05 & $0.00 * * *$ & $-6.24^{* * *}$ & 0.05 & $0.00^{* * *}$ \\
\hline $\mathrm{N}$ individuals & & 4,981 & & & 4,981 & \\
\hline $\mathrm{N}$ observations & & 39,833 & & & 39,833 & \\
\hline AIC & & 24,783 & & & 24,701 & \\
\hline Marginal probability & & 0.10 & & & 0.10 & \\
\hline Repeated likelihood $^{\text {a }}$ & & 5.40 & & & 5.29 & \\
\hline
\end{tabular}

a Intra-class manifest association (Rodríguez \& Elo 2003)

Significant at ${ }^{* *} 0.001 * * 0.01 * 0.05$; models control for yearly dummy variables

SOEP 2000-2010, own calculations 
Model II includes the Big Five and LoC (Table 8), and shows that certain personality traits matter for FET participation; yet, effects are quite different compared to the trait-only model (Table 7). Only Openness and LoC remain significant predictors, also in the expected direction, whereas the other traits are rendered or remain insignificant. Individuals who report a one SD greater score on Openness have a participation likelihood of 13.3 percent in any one year compared to 'average' open individuals with a likelihood of 10 percent, all else equal. With a similar effect size, respondents with a one SD more internal LoC are 1.35 times more likely to train, a marginal probability of 13.5 percent. Taken together, a person who is both one SD higher than the population's mean in Openness and LoC would have a marginal probability of participation of 16.8 percent in any given year which is more than 1.5 times than the average person.

Fit statistics are shown in the lower part of Table 8. With the addition of personality, the AIC decreases roughly by 80 points, meaning that the second model fits the data considerably better compared to the model without those variables (Burnham \& Anderson 2004). The repeated likelihood measures may be interpreted as a kind of odds-ratio for the dependent variable on itself (Rodríguez \& Elo 2003), and suggest that those who participate in FET are over five times more likely to participate again in a later year; this goes in line with my previous research on multiple training engagements understood as prolonged educational careers. Hence, one of the large benefits of this analysis is that the model estimates are less biased by the endogeneity of previous participation.

In order to check the robustness of my findings, I specify five alternative models. First, these models were run separately for men and women (see Appendix Table 13). The results show that certain socio-economic characteristics (especially education and employment-related factors) have somewhat different effects for both sexes; however, personality coefficients are similar both in size and direction for men and women, with the exception of Openness, where the effect is larger for females. Next I run models with alternative variable configurations. The first of these sensitivity models (Model S1, Appendix Table 14) adds variables for industry sector and firm size. As personality characteristics could shape work-related preferences (Holland 1997), individuals with certain trait profiles might self-select into different sectors where specific characteristics are more demanded or rewarded. Also, research shows that FET varies by industry with those working in public service, insurance and banking or education are more likely to train compared to those in construction or manufacturing (Offerhaus et al. 2010). In Model S2, I speci- 
fy a hybrid model permitting time-varying and time-constant effects (Rabe-Hesketh \& Skrondal 2005). Ultimately, this controls for potentially hidden properties of time-varying covariates to explain effects of personality trait measures on FET. Model S3 adds quadratic personality measures in order to test for non-linearities (similar to Heineck \& Anger 2010; Mueller \& Plug 2006). Finally, Model S4 looks only at the three waves which feature the detailed training modules (2000, 2004, and 2008), thus uses less observations and a restricted version of the FET measure.

Overall, in the additional model specifications, the effects of Openness and LoC are almost identical to the original model (Table 8); these two traits remain consistent and comparatively strong predictors for FET participation. In Model S4, the hypothesized negative effect of Agreeableness appears, yet is only marginally significant. Most interesting are the results from Model S3. As expected, Openness and LoC have significant positive impacts on training participation. The insignificant squared term of Openness supports the original effect: more open individuals are more likely to train. For LoC the overall positive effect of internal control beliefs takes a negative turn for those with exceptionally high values; however the main story of more internal control leading to more participation remains intact. Finally, for Conscientiousness the significant negative coefficient for the squared term shows that the training likelihood for extremely thorough individuals declines in a non-linear manner; Conscientiousness does not matter except in its most extreme forms where it reduces chances of FET participation.

Generally, despite some variation in the various model specifications, it appears to be that the type to train is an individual who is open to new experiences and has internalized control beliefs; thus, those two personality characteristics are not only associated with a higher willingness to train but also an increased probability of actual participation in training.

\section{Discussion and conclusion}

This research utilizes a psychological construct - personality - in order to explain participation in employment-related FET. Although it shows that trait profiles of training participants are significantly different for Extraversion, Openness, Neuroticism, and LoC compared to those who 
never participated in training, only Openness and LoC prove to be significant predictors of FET participation between 2000 and 2008. More open individuals tend to be more curious, broadminded and eager to acquire new skills (Major et al. 2006); they seem to deliberately seek opportunities to engage in FET. Individuals with more internal control beliefs have high task motivation and strong goal setting (Erez \& Judge 2001), show greater initiative, and higher willingness and determination to reach certain outcomes, also leading to higher FET rates. They are described as "choice making agents" (Ng et al. 2006: 1060), making the choice to train, just for the sake of training or as a mean to attain better employment prospects, higher incomes or to maintain job security, for instance.

Contrary to the hypotheses, Agreeableness, Extraversion and Neuroticism do not have an impact on FET participation. Also, Conscientiousness does not have the expected effect, although it might matter in extreme forms as one of the sensitivity tests revealed. Yet, given the nature of FET in Germany, these findings are not too surprising as individuals often do not have full control over the training decision. Training is often, especially in the public sector, a normal and regularly occurring by-product of employment careers. Also, in case the organizational environment provides a strong support structure for FET participation, individual personality characteristics should play a minor role. Additional information about the nature of the training course would be needed to investigate the relationship of personality and training more closely, and to uncover the potential differential impact of traits on various FET types.

Overall, these analyses show that it is crucial to account for traits in training research. Considering personality characteristics may also be the key to increase participation rates for those who normally would not engage in training. For example, employees could be more involved in the training decision-making process by being given a choice of which course(s) they would want to participate in; this might trigger individual internal control beliefs or stimulate curiosity. Generally, employee participation in decision-making processes increases the commitment to the outcome, especially when less preferred options are at hand (for example, Parker et al. 1997). In the context of personality and training, it is also important to focus on the respective personality fit in order to improve the training experience and enhance post-training transfer and performance. Offering professionally demand-tailored FET courses, which match the different preferences and personalities, may increase training participation and its effectiveness. This highlights the context in which training takes place. As already mentioned, Holland (1997) offers a typology of 
occupational preferences; individuals choose career tracks and work environments which suit their different personalities. For instance, the investigative (i.e. more open) type is likely to have scientific abilities and prefers analytically demanding tasks, the social (i.e. extroverted) one favors jobs which involve communication and relationships with others, whereas an individual with conventional interests (i.e. conscientious) prefers structured work environments and regulated activities. Concerning FET, individuals could have similar preferences in regard to the training situation itself: the social type might enjoy learning in groups better than the conventional type who may favor self-guided learning. So offering different styles of training courses which better suit the various types to train might increase participation and make FET a more desirable and rewarding experience.

Despite the strengths of the analyses, especially the large sample size, the nine-year observation window, rigorous testing of trait stability and various model specifications, this research is not without limitations. First, personality traits may be susceptible to measurement error, because individuals differ in the accuracy of self-assessment, vary in the extent to which they actually know themselves (denial) and may be subject to socially desirable personality reporting. However, this issue is dealt with using factor measurement models as the best possible solution. Additionally, despite efforts to improve accuracy of the FET measure, it does not fully capture all training events and especially neglects informal and self-directed learning activities. Furthermore, this research does not differentiate between voluntary and obligatory participation. Future research should focus on this distinction, particularly with regards to underlying motivation which may be a crucial mediating factor in the personality-training-relationship. It could be assumed that motivation reinforces the impact of personality characteristics, whereas the absence of motivation attenuates it. Yet, motivation or training willingness is difficult to capture with the SOEP, which unfortunately does not measure who initiated participation in FET. Using the questions Did the course take place during working hours? and How high were the costs you had to pay yourself? does not depict whether the training decision was made by the employee or the employer. In addition to controlling for motivation, it might be interesting to consider other measures of personality besides the Big Five and LoC, for example self-efficacy, self-esteem, general curiosity or anxiety. 


\section{References}

Bandura, A., \& Wood, R. E. (1989). Effect of Perceived Controllability and Performance Standards on SelfRegulation of Complex Decision-Making. Journal of Personality and Social Psychology, 56(5), 805-814.

Barrick, M. R., \& Mount, M. K. (1991). The Big Five Personality Dimensions and Job Performance. A MetaAnalysis. Personnel Psychology, 44(1), 1-26.

Becker, G. S. (1962). Investment in Human Capital: A Theoretical Analysis. Journal of Political Economy, 70 $(5 / 2), 9-49$.

Blanden, J., Gregg, P., \& Macmillan, L. (2007). Accounting for Intergenerational Income Persistence. NonCognitive Skills, Ability and Education. The Economic Journal, 117(519), 43-60.

Bono, J. E., \& Judge, T. A. (2003). Core Self-Evaluations: A Review of the Trait and its Role in Job Satisfaction and Job Performance. European Journal of Personality, 17(1), 5-18.

Borghans, L., Duckworth, A. L., Heckman, J. J., \& ter Weel, B. (2008). The Economics and Psychology of Personality Traits. Journal of Human Resources, 43(4), 972-1059.

Bowles, S., Gintis, H., \& Osborne, M. (2001). The Determinants of Earnings: A Behavioral Approach. Journal of Economic Literature, 39(4), 1137-1176.

Braakmann, N. (2009). The Role of Psychological Traits for the Gender Gap in Full-Time Employment and Wages: Evidence from Germany. SOEP Papers on Multidisciplinary Panel Data Research No. 162. German Institute for Economic Research (DIW), Berlin.

Burnham, K. P., \& Anderson, D. R. (2004). Multimodel Inference. Understanding AIC and BIC in Model Selection. Sociological Methods \& Research, 33(2), 261-304.

Caliendo, M., Fossen, F. M., \& Kritikos, A. S. (2011). Personality Characteristics and the Decision to Become and Stay Self-Employed. IZA Discussion Paper No. 5566, Institute for the Study of Labor (IZA), Bonn.

Caliendo, M., Cobb-Clark, D., \& Uhlendorff, A. (2010). Locus of Control and Job Search Strategies. SOEP Papers on Multidisciplinary Panel Data Research No. 979. German Institute for Economic Research (DIW), Berlin.

Caliendo, M., Fossen, F. M., \& Kritikos, A. (2009). Risk Attitudes of Nascent Entrepreneurs. New Evidence from an Experimentally Validated Survey. Small Business Economics, 32(2), 153-167.

Caspi, A., \& Roberts, B. W. (1999). Personality Continuity and Change across the Life Course. In Pervin, L. A. \& John, O.P. (Eds.), Handbook of Personality: Theory and Research. New York: Guilford, 300-326.

Caspi, A., Roberts, B. W., \& Shiner, R. L. (2005). Personality Development. Stability and Change. Annual Review of Psychology, 56, 453-484. 
Coleman, J. S., Campbell, E. Q., Hobson, C. J., McPartland, F., Mood, A. M., Weinfeld, F. D., et al. (1966). Equality of Educational Opportunity. United States Office of Education. Washington, DC: U.S. Government Printing Office.

Coleman, M., \& DeLeire, T. (2003). An Economic Model of Locus of Control and the Human Capital Investment Decision. Journal of Human Resources, 38(3), 701-721.

Colquitt, J. A., Lepine, J. A., \& Noe, R. A. (2000). Toward an Integrative Theory of Training Motivation. A Meta-Analytic Path Analysis of 20 Years of Research. Journal of Applied Psychology, 85(5), 678-707.

Cortina, J. M. (1993). What is Coefficient Alpha? An Examination of Theory and Applications. Journal of Applied Psychology, 78(1), 98-104.

Costa, P. T., \& McCrae, R. R. (1994). Set Like Plaster: Evidence of the Stability of Adult Personality. In: Heatherton, T. F. \& Weinberger, J. L. (Eds.), Can Personality Change? American Psychological Association: Washington, DC, 21-40.

Costa, P. Z., Herbst, J. H., McCrae, R. R., \& Siegler, I. C. (2000). Personality at Midlife: Stability, Intrinsic Maturation, and Response to Life Events. Assessment, 7(4), 365-378.

Dehne, M., \& Schupp, J. (2007). Persönlichkeitsmerkmale im Sozio-ökonomischen Panel (SOEP). Konzept, Umsetzung und empirische Eigenschaften. SOEP Research Notes No. 26, German Institute for Economic Research (DIW), Berlin.

Deutscher Bildungsrat (1970). Empfehlungen der Bildungskommission. Strukturplan für das Bildungswesen. Stuttgart: Klett Verlag.

Dittman, J., \& Goebel, J. (2010). Your House, Your Car, Your Education. The Socioeconomic Situation for the Neighborhood and its Impact on Life Satisfaction in Germany. Social Indicators Research, 96(3), 487-513.

Erez, A., \& Judge, T. A. (2001). Relationship of Core Self-Evaluations to Goal Setting, Motivation and Performance. Journal of Applied Psychology, 86(6), 1270-1279.

Frees, E. W. (2004). Longitudinal and Panel Data. Analysis and Applications in the Social Sciences. Cambridge: Cambridge University Press.

Fritsch, M., \& Rusakova, A. (2010). Personality Traits, Self-Employment, and Professions. SOEP Papers on Multidisciplinary Panel Data Research No. 343. German Institute for Economic Research (DIW), Berlin.

Fouarge, D., Schils, T., \& de Grip, A. (2012). Why Do Low-Educated Workers Invest Less in Further Training. Applied Economics. Advance online access: 10.1080/00036846.2012.671926.

Gerlitz, J.-Y., \& Schupp, J. (2005). Zur Erhebung der Big-Five-basierten Persönlichkeitsmerkmale im SOEP. SOEP Research Notes No. 4, German Institute for Economic Research (DIW), Berlin.

Goldberg, L. R. (1990). An Alternative 'Description of Personality': The Big-Five Factor Structure. Journal of Personality and Social Psychology, 59(6), 1216-1229. 
Görlitz, K., \& Tamm, M. (2012). Revisiting the Complementarity between Education and Training: The Role of Personality, Working Tasks and Firm Effects. SOEP Papers on Multidisciplinary Panel Data Research No. 477. German Institute for Economic Research (DIW), Berlin.

Greene, R. L. (1986). Sources of Recency Effects in Free Recall. Psychological Bulletin, 99(2), 221-228.

Groves, M. (2005). How Important is Your Personality? Labor Market Returns to Personality for Women in the US and UK. Journal of Economic Psychology, 26(6), 827-841.

Hartman, R. O., \& Betz, N. E. (2007). The Five-Factor Model and Career Self-Efficacy. General and Domain-Specific Relationships. Journal of Career Assessment, 15(2), 145-161.

Heady, B. (2008). Life Goals Matter to Happiness: A Revision of Set-Point Theory. Social Indicators Research, 86(2), 213-231.

Heckman, J. J., \& Rubinstein, Y. (2001). The Importance of Noncognitive Skills. Lessons from the GED Testing Program. American Economic Review, 91(2), 145-149.

Heckman, J. J., Stixrud, J., \& Urzua, S. (2006). The Effect of Cognitive and Noncognitive Abilities on Labor Market Outcomes and Social Behavior. Journal of Labor Economics, 24(3), 411-482.

Heineck, G. (2011). Does It Pay to Be Nice? Personality and Earnings in the U.K. Industrial and Labor Relations Review, 64(5), 1020-1038.

Heineck, G., \& Anger, S. (2010). The Returns to Cognitive Abilities and Personality Traits in Germany. Labour Economics, 17(3), 535-546.

Holland, J. L. (1997). Making Vocational Choices. A Theory of Vocational Personalities and Work Environments. Odessa: Psychological Assessment Research Inc.

Hubert, T., \& Wolf, C. (2007). Determinanten der beruflichen Weiterbildung Erwerbstätiger: Empirische Analysen auf der Basis des Mikrozensus 2003. Zeitschrift für Soziologie, 36(6), 473-493.

Infurna, F. J., Gerstorf, D., \& Zarit, S. H. (2011). Examining Dynamic Links Between Mastery and Health. Longitudinal Evidence for Differential Effects in Midlife and Old Age. Developmental Psychology, 47(1), 9-18.

Jackson, M. (2006). Personality Traits and Occupational Attainment. European Sociological Review, 22(2), 187-199.

Jencks, C., Bartlett, S., Corcoran, M., Crouse, J., Eaglesfield, D., Jackson, G., et al. (1979). Who Gets Ahead? The Determinants of Economic Success in America. New York: Basic Books, Inc. Publishers.

Judge, T. A., Higgins, C. A., Thoresen, C. J., \& Barrick, M. R. (1999). The Big Five Personality Trait, General Mental Ability, and Career Success Across the Life Span. Personnel Psychology, 52(3), 621-652.

Konsortium Bildungsberichterstattung (2012). Bildung in Deutschland. Ein indikatorengestützter Bericht mit einer Analyse zur kulturellen Bildung im Lebensverlauf. Bielefeld, W. Bertelsmann Verlag.

Krampen, G. (1981). IPC-Fragebogen zu Kontrollüberzeugungen. Göttingen: Hogrefe. 
Kuwan, H., Bilger, F., Gnahs, D., \& Seidel, S. (2006). Berichtssystem Weiterbildung IX. Integrierter Gesamtbericht zur Weiterbildungssituation in Deutschland. Bundesministerium für Bildung und Forschung, Bonn.

Major, D. A., Turner, J. E., \& Fletcher, T. D. (2006). Linking Proactive Personality and the Big Five to Motivation to Learn and Development Activity. Journal of Applied Psychology, 91(4), 927-935.

McCrae, R. R., \& Costa Jr., P. T. (1999). A Five-Factor Theory of Personality. In Pervin, L. A. \& John, O. P. (Eds.), Handbook of Personality. Theory and Research. New York: Guilford Press, 139-153.

Mirowsky, J., \& Ross, C. E. (2007). Life Course Trajectories of Perceived Control and Their Relationships to Education. American Journal of Sociology, 112(5), 1339-1382.

Mood, C., Jonsson, J. O., \& Bihagen, E. (2012). Socioeconomic Persistence Across Generations. Cognitive and Noncognitive Processes. In Ermisch, J., Jäntti, M., \& Smeeding, T. M. (Eds.), From Parents to Children. The Intergenerational Transmission of Advantage. New York: Russel Sage Foundation, 53-83.

Mueller, G., \& Plug, E. (2006). Estimating the Effect of Personality on Male-Female Earnings. Industrial \& Labor Relations Review, 60(1), 3-22.

Ng, T. W. H., Sorensen, K. L., \& Eby, L. T. (2006). Locus of Control at Work: A Meta-Analysis. Journal of Organizational Behavior, 27(8), 1057-1087.

Nyhus, E. K., \& Pons, E. (2005). The Effects of Personality on Earnings. Journal of Economic Psychology, 26(3), 363-384.

Offerhaus, J., Leschke, J., \& Schömann, K. (2010). Soziale Ungleichheit im Zugang zu beruflicher Weiterbildung. In: Becker, R. \& Lauterbach, W. (Eds.), Bildung als Privileg? Erklärungen und Befunde zu den Ursachen der Bildungsungleichheit. Wiesbaden: VS Verlag, 345-376.

Parker, S. K., Chmiel, N., \& Wall, T. D. (1997). Work Characteristics and Employee Well-Being Within a Context of Strategic Downsizing. Journal of Occupational Health Psychology, 2(4), 289-303.

Piatek, R., \& Pinger, P. (2010). Maintaining (Locus of) Control? Assessing the Impact of Locus of Control on Education Decisions and Wages. SOEP Papers on Multidisciplinary Panel Data Research No. 338. German Institute for Economic Research (DIW), Berlin.

Prociuk, T. J., \& Breen, L. J. (1975). Defensive Externality and its Relation to Academic Performance. Journal of Personality and Social Psychology, 31(3), 549-556.

Protsch, P., \& Dieckhoff, M. (2011). What Matters in the Transition from School to Vocational Training in Germany? Educational Credentials, Cognitive Abilities or Personality? European Societies, 13(1), 6991.

Rabe-Hesketh, S., \& Skrondal, A. (2005). Multilevel and Longitudinal Modeling Using Stata. College Station: Stata Press.

Rammstedt, B. (2007). Who Worries and Who is Happy? Explaining Individual Differences in Worries and Satisfaction by Personality. Personality and Individual Differences, 43(6), 1626-1634. 
Rodríguez, G., \& Elo, I. (2003). Intra-Class Correlation in Random-Effects Models for Binary Data. The Stata Journal, 3(1), 32-46.

Roberts, B. W. (2009). Back to the Future. Personality and Assessment and Personality Development. Journal of Research in Personality, 43(2), 137-145.

Roberts, B. W., \& Jackson, J. J. (2008). Sociogenomic Personality Psychology. Journal of Personality, 76(6), 1523-1544.

Roberts, B. W., Wood, D., \& Caspi, A. (2008). The Development of Personality Traits in Adulthood. In John, O. P., Robins, R. W. \& Pervin, L. A. (Ed.), Handbook of Personality: Theory and Research. New York: Guilford, 375-398.

Roberts, B. W., Kuncel, N. R., Shiner, R., Caspi, A., \& Goldberg, L.R. (2007). The Power of Personality: The Comparative Validity of Personality Traits, Socioeconomic Status, and Cognitive Abilities for Predicting Important Life Outcomes. Perspectives of Psychological Science, 2(4), 313-345.

Roberts, B. W., Walton, K. E., \& Viechtbauer, W. (2006). Patterns of Mean-Level Change in Personality Traits Across the Life Course: A Meta-Analysis of Longitudinal Studies. Psychological Bulletin, 132(1), 1-25.

Roberts, B.W, Caspi, A., \& Moffitt, T. E. (2003). Work Experience and Personality Development in Young Adulthood. Journal of Personality and Social Psychology, 84(3), 582-593.

Rotter, J. B. (1975). Some Problems and Misconceptions Related to the Construct of Internal Versus External Control of Reinforcement. Journal of Consulting and Clinical Psychology, 43(1), 56-67.

Rotter, J. B. (1966). Generalized Expectancies for Internal versus External Control of Reinforcement. Psychological Monographs: General \& Applied, 80(1), 1-28.

Semykina, A. \& Linz, S. J. (2007). Gender Differences in Personality and Earning: Evidence from Russia. Journal of Economic Psychology, 28(3), 387-410.

Seibert, S. E., \& Kraimer, M. L. (2001). The Five-Factor Model of Personality and Career Success. Journal of Vocational Behavior, 58(1), 1-21.

Solga, H., \& Kohlrausch, B. (2012). How Low-Achieving German Youth Beat the Odds and Gain Access to Vocational Training - Insights from Within-Group Variation. European Sociological Review. Advance online access doi: $10.1093 /$ esr/jcs083.

Specht, J., Egloff, B., \& Schmukle, S. C. (2012). Examining Mechanisms of Personality Maturation. The Impact of Life Satisfaction on the Development of the Big Five Personality Traits. Social Psychology and Personality Science. Advance online access doi: 10.1177/1948550612448197.

Specht, J., Egloff, B., \& Schmukle, S. C. (2011). Stability and Change of Personality Across the Life Course: The Impact of Age and Major Life Events on Mean-Level and Rank-Order Stability of the Big Five. Journal of Personality and Social Psychology, 101(4), 862-882.

Trzcinski, E., \& Holst, E. (2012). Gender Differences in Subjective Well-Being In and Out of Management Positions. Social Indicators Research, 107(3), 449-463. 
Trzcinski, E., \& Holst, E. (2010). Interrelationships Among Locus of Control and Years in Management and Unemployment. Differences by Gender. SOEP Papers on Multidisciplinary Panel Data Research No. 266. German Institute for Economic Research (DIW), Berlin.

Uhlendorff, A. (2004). Der Einfluss von Persönlichkeitseigenschaften und sozialen Ressourcen auf die Arbeitslosigkeitsdauer. Kölner Zeitschrift für Soziologie und Sozialpsychologie, 56(2), 279-303.

Uysal, S. D., \& Pohlmeier, W. (2011). Unemployment Duration and Personality. Journal of Economic Psychology, 32(6), 980-992.

Viinikainen, J., \& Kokko, K. (2012). Personality Traits and Unemployment: Evidence from Longitudinal Data. Journal of Economic Psychology. Advance online access doi: 10.1016/joep.2012.09.001.

Wagner, G. G., Frick, J. R. \&, Schupp, J. (2007). The German Socio-Economic Panel Study (SOEP): Scope, Evolution and Enhancements. Journal of Applied Social Science Studies, 127(1), 139-170.

Wichert, L., \& Pohlmeier, W. (2010). Female Labor Force Participation and the Big Five. ZEW Discussion Papers 10-003, Centre of European Economic Research (ZEW), Mannheim.

Wooldridge, J. M. (2010). Econometric Analysis of Cross-Section and Panel Data. Cambridge: MIT Press.

Wortman, J., Lucas, R. E., \& Donnellan, M. B. (2012). Stability and Change in the Big Five Personality Domains: Evidence from a Longitudinal Study of Australian. Psychology and Aging. Advance online access doi:10.1037/a0029322.

The data used was made available by the Socio-Economic Panel (SOEP v27, 2011), data for years 19842010, doi:10.5684/soep.v27). 


\section{Appendix}

Table 9 Inter-item correlation of personality traits

\begin{tabular}{|c|c|c|c|c|c|c|c|c|c|c|c|c|c|c|c|c|c|c|c|c|c|c|c|c|c|}
\hline & \multicolumn{3}{|c|}{ Consc } & \multicolumn{3}{|c|}{ Agree } & \multicolumn{3}{|c|}{ Extra } & \multicolumn{3}{|c|}{ Open } & \multicolumn{3}{|c|}{ Neuro } & \multicolumn{10}{|c|}{ LoC (external-internal) } \\
\hline & 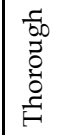 & 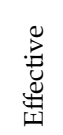 & $\begin{array}{l}\vec{N} \\
\text { త్ }\end{array}$ & $\frac{\stackrel{0}{\vec{Z}}}{\simeq}$ & 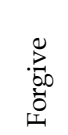 & $\begin{array}{l}\vec{B} \\
\text { 过 }\end{array}$ & 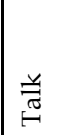 & $\begin{array}{l}\widetilde{J} \\
\stackrel{\Xi}{0} \\
\mathbb{D} \\
\simeq\end{array}$ & 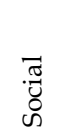 & $\begin{array}{l}\tilde{\infty} \\
\widetilde{\Xi} \\
\Xi\end{array}$ & $\begin{array}{l}\overrightarrow{\widetilde{J}} \\
\stackrel{\widetilde{\sigma}}{\tilde{\sigma}} \\
\end{array}$ & 荣 & $\begin{array}{l}\overrightarrow{0} \\
3\end{array}$ & $\begin{array}{l}0 \\
0 \\
己 \\
Z \\
Z\end{array}$ & $\begin{array}{l}\text { Dे } \\
\text { फे }\end{array}$ & 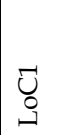 & ర్ & ర్త & $\begin{array}{l}\underset{O}{J} \\
\text { J }\end{array}$ & $\begin{array}{l}13 \\
0 \\
0 \\
\end{array}$ & త్త & U్ & $\begin{array}{l}\infty \\
0 \\
0 \\
\beta\end{array}$ & రి & $\begin{array}{l}\circ \\
\text { Ü } \\
0\end{array}$ \\
\hline Thorough & 1 & & & & & & & & & & & & & & & & & & & & & & & & \\
\hline Effective & .55 & 1 & & & & & & & & & & & & & & & & & & & & & & & \\
\hline Lazy & .40 & .31 & 1 & & & & & & & & & & & & & & & & & & & & & & \\
\hline Rude & .10 & .08 & .22 & 1 & & & & & & & & & & & & & & & & & & & & & \\
\hline Forgive & .15 & .20 & .17 & .19 & 1 & & & & & & & & & & & & & & & & & & & & \\
\hline Kind & .29 & .34 & .25 & .42 & .37 & 1 & & & & & & & & & & & & & & & & & & & \\
\hline Talk & .26 & .28 & .18 & .00 & .21 & .30 & 1 & & & & & & & & & & & & & & & & & & \\
\hline Reserved & -.03 & .01 & .03 & -.13 & -.03 & -.10 & .37 & 1 & & & & & & & & & & & & & & & & & \\
\hline Social & .17 & .27 & .11 & -.02 & .21 & .27 & .62 & .38 & 1 & & & & & & & & & & & & & & & & \\
\hline Image & .10 & .17 & -.03 & -.04 & .13 & .22 & .35 & .14 & .35 & 1 & & & & & & & & & & & & & & & \\
\hline Original & .21 & .30 & .05 & -.15 & .11 & .13 & .41 & .22 & .39 & .48 & 1 & & & & & & & & & & & & & & \\
\hline Art & .10 & .15 & .03 & .08 & .10 & .20 & .25 & .04 & .27 & .38 & .38 & 1 & & & & & & & & & & & & & \\
\hline Worry & .09 & .03 & .08 & -.06 & .08 & .12 & .02 & -.15 & -.01 & .05 & -.01 & .05 & 1 & & & & & & & & & & & & \\
\hline Nervous & -.08 & -.11 & -.09 & -.15 & -.06 & -.04 & -.07 & -.17 & -.07 & .02 & -.09 & .04 & .41 & 1 & & & & & & & & & & & \\
\hline Stress & -.15 & -.23 & -.08 & -.09 & -.15 & -.19 & -.17 & -.05 & -.19 & -.15 & -.21 & -.10 & .30 & .47 & 1 & & & & & & & & & & \\
\hline LoC1 & .18 & .23 & .07 & -.02 & .11 & .14 & .17 & .07 & .19 & .11 & .16 & .07 & -.12 & -.11 & -.20 & 1 & & & & & & & & & \\
\hline LoC2 & -.06 & -.12 & -.05 & -.12 & -.09 & -.12 & -.07 & -.08 & -.06 & -.02 & -.05 & -.08 & .22 & .15 & .12 & -.20 & 1 & & & & & & & & \\
\hline LoC3 & -.03 & -.06 & -.01 & .00 & -.03 & -.02 & -.05 & -.09 & -.04 & -.02 & -.07 & -.04 & .16 & .11 & .05 & -.19 & .35 & 1 & & & & & & & \\
\hline LoC4 & -.04 & -.03 & -.09 & -.01 & .01 & .00 & .03 & -.02 & .01 & .08 & .08 & .18 & -.10 & -.01 & -.06 & .10 & -.05 & .04 & 1 & & & & & & \\
\hline LoC5 & -.12 & -.15 & -.10 & -.09 & -.08 & -.13 & -.09 & -.12 & -.11 & .01 & -.05 & -.02 & .20 & .17 & .16 & -.34 & .37 & .27 & .01 & 1 & & & & & \\
\hline LoC6 & .24 & .24 & .18 & .03 & .15 & 19 & .14 & -.01 & .15 & .06 & .09 & .03 & .14 & -.02 & -.07 & .25 & .01 & .01 & -.03 & -.06 & 1 & & & & \\
\hline LoC7 & -.16 & -.25 & -.15 & -.07 & -.12 & -.08 & -.16 & -.20 & -.15 & -.06 & -.21 & -.01 & .30 & .35 & .29 & -.19 & .29 & .25 & .06 & .39 & -.05 & 1 & & & \\
\hline LoC8 & .00 & -.02 & -.04 & -.01 & .00 & .03 & .00 & -.06 & -.01 & .03 & -.03 & .03 & .18 & .12 & .08 & -.16 & .23 & .27 & .02 & .28 & .08 & .27 & 1 & & \\
\hline LoC9 & .12 & .13 & .07 & -.02 & .07 & .12 & .09 & -.03 & .11 & .07 & .11 & .05 & .10 & .04 & -.06 & .18 & .11 & .19 & .02 & .03 & .21 & .05 & .19 & 1 & \\
\hline LoC10 & -.17 & -.23 & -.12 & -.08 & -.11 & -.16 & -.16 & -.13 & -.17 & -.07 & -.15 & -.08 & .16 & .18 & .16 & -.39 & .39 & .39 & .01 & .50 & .15 & .41 & .25 & .03 & 1 \\
\hline
\end{tabular}

${ }^{a}$ Item 4 dropped from the Locus of Control factor

SOEP 2005, 2009 and 2010, own calculations 
Table 10 Autocorrelation across measurement times for personality traits and respective items

\begin{tabular}{|c|c|c|c|c|c|}
\hline \multicolumn{3}{|c|}{ Conscientiousness $\quad(0.50)$} & \multicolumn{3}{|c|}{ Agreeableness $\quad(0.51)$} \\
\hline Thorough & Effective & Lazy & Rude & Forgive & Kind \\
\hline 0.42 & 0.37 & 0.42 & 0.45 & 0.39 & 0.38 \\
\hline \multicolumn{3}{|c|}{ Extraversion $\quad(0.62)$} & \multicolumn{3}{|c|}{ Openness $(0.58)$} \\
\hline Talk & Reserved & Social & Image & Original & Art \\
\hline 0.53 & 0.44 & 0.54 & 0.46 & 0.45 & 0.52 \\
\hline \multicolumn{6}{|c|}{ Neuroticism $\quad(0.57)$} \\
\hline Worry & Nervous & Stress & & & \\
\hline 0.46 & 0.44 & 0.41 & & & \\
\hline \multirow{4}{*}{$\begin{array}{c}\text { Locus of } \\
\text { Control } \\
(0.52)\end{array}$} & LoC1 & LoC2 & LoC3 & LoC4 & LoC5 \\
\hline & 0.36 & 0.32 & 0.40 & * & 0.36 \\
\hline & LoC6 & LoC7 & LoC8 & LoC9 & LoC10 \\
\hline & 0.33 & 0.38 & 0.25 & 0.25 & 0.34 \\
\hline
\end{tabular}

* Item 4 dropped from the Locus of Control factor

SOEP 2005, 2009 and 2010, own calculations 
Table 11 Descriptive statistics for all variables

\begin{tabular}{|c|c|c|c|c|c|}
\hline Variable & $\mathrm{N}^{\mathrm{a}}$ & Mean & SD & Min & Max \\
\hline FET participation & 39,833 & 0.13 & 0.34 & 0 & 1 \\
\hline Female & 39,833 & 0.48 & 0.50 & 0 & 1 \\
\hline Age & 39,833 & 42.3 & 9.84 & 18 & 64 \\
\hline Age $^{2}$ & 39,833 & 1885.6 & 834.15 & 324 & 4096 \\
\hline Married & 39,833 & 0.68 & 0.47 & 0 & 1 \\
\hline Divorced & 39,833 & 0.11 & 0.32 & 0 & 1 \\
\hline Children under 16 & 39,833 & 0.41 & 0.49 & 0 & 1 \\
\hline East & 39,833 & 0.71 & 0.46 & 0 & 1 \\
\hline Migration & 39,833 & 0.18 & 0.38 & 0 & 1 \\
\hline Full-time employment & 39,833 & 0.67 & 0.47 & 0 & 1 \\
\hline Part-time employment & 39,833 & 0.22 & 0.41 & 0 & 1 \\
\hline Education low & 39,833 & 0.33 & 0.47 & 0 & 1 \\
\hline Education intermediate & 39,833 & 0.46 & 0.50 & 0 & 1 \\
\hline Education high & 39,833 & 0.21 & 0.41 & 0 & 1 \\
\hline EGP Missing & 39,833 & 0.01 & 0.10 & 0 & 1 \\
\hline EGP Unemployed & 39,833 & 0.10 & 0.30 & 0 & 1 \\
\hline EGP Service class & 39,833 & 0.31 & 0.46 & 0 & 1 \\
\hline EGP Intermediate & 39,833 & 0.10 & 0.30 & 0 & 1 \\
\hline EGP Working class & 39,833 & 0.25 & 0.43 & 0 & 1 \\
\hline EGP Routine working & 39,833 & 0.17 & 0.37 & 0 & 1 \\
\hline EGP Self-employed & 39,833 & 0.06 & 0.24 & 0 & 1 \\
\hline Permanent contract & 39,833 & 0.29 & 0.45 & 0 & 1 \\
\hline Temporary contract & 39,833 & 0.49 & 0.50 & 0 & 1 \\
\hline Private sector & 39,833 & 0.23 & 0.42 & 0 & 1 \\
\hline Conscientiousness & 39,833 & 0.04 & 0.75 & -3.79 & 1.03 \\
\hline Agreeableness & 39,833 & -0.02 & 0.73 & -3.34 & 1.33 \\
\hline Extraversion & 39,833 & 0.01 & 0.82 & -3.05 & 1.58 \\
\hline Openness & 39,833 & 0.01 & 0.76 & -2.62 & 1.85 \\
\hline Neuroticism & 39,833 & -0.03 & 0.76 & -2.03 & 2.26 \\
\hline Locus of Control & 39,833 & 0.03 & 0.85 & -3.89 & 2.23 \\
\hline
\end{tabular}

a 4,981 individuals pooled over 9 years

SOEP 2000-2010, own calculations 
Table 12 Correlation matrix for all variables

\begin{tabular}{|c|c|c|c|c|c|c|c|}
\hline & FET & Consc & Agree & Extra & Open & Neuro & LoC \\
\hline FET participation & 1.00 & & & & & & \\
\hline Conscientiousness & -0.00 & 1.00 & & & & & \\
\hline Agreeableness & -0.00 & 0.33 & 1.00 & & & & \\
\hline Extraversion & 0.03 & 0.25 & 0.21 & 1.00 & & & \\
\hline Openness & 0.07 & 0.20 & 0.16 & 0.46 & 1.00 & & \\
\hline Neuroticism & -0.04 & -0.12 & -0.12 & -0.13 & -0.07 & 1.00 & \\
\hline Locus of Control & 0.09 & 0.22 & 0.16 & 0.18 & 0.10 & -0.33 & 1.00 \\
\hline Female & 0.00 & 0.07 & 0.21 & 0.16 & 0.07 & 0.21 & -0.03 \\
\hline Age & -0.05 & 0.05 & 0.02 & -0.07 & -0.02 & 0.06 & -0.06 \\
\hline Age $^{2}$ & -0.06 & 0.04 & 0.02 & -0.07 & -0.02 & 0.06 & -0.06 \\
\hline Married & -0.03 & 0.07 & 0.03 & -0.03 & -0.07 & 0.03 & 0.02 \\
\hline Divorced & 0.00 & 0.02 & 0.04 & 0.04 & 0.06 & 0.03 & -0.03 \\
\hline Children under 16 & 0.00 & 0.02 & 0.02 & 0.04 & -0.01 & -0.01 & 0.04 \\
\hline East & -0.02 & 0.00 & 0.00 & 0.02 & 0.00 & -0.05 & 0.05 \\
\hline Migration & -0.08 & 0.02 & 0.06 & 0.00 & -0.03 & 0.02 & -0.07 \\
\hline Full-time employment & 0.07 & 0.04 & -0.12 & -0.06 & 0.00 & -0.17 & 0.12 \\
\hline Part-time employment & -0.03 & 0.00 & 0.13 & 0.08 & 0.02 & 0.14 & -0.01 \\
\hline Education low & -0.14 & 0.01 & -0.03 & -0.04 & -0.14 & 0.06 & -0.14 \\
\hline Education intermediate & 0.02 & 0.04 & 0.02 & 0.05 & 0.02 & -0.01 & 0.05 \\
\hline Education high & 0.14 & -0.06 & 0.02 & -0.01 & 0.14 & -0.06 & 0.09 \\
\hline EGP Missing & -0.01 & 0.00 & 0.01 & 0.00 & 0.00 & 0.01 & -0.01 \\
\hline EGP Unemployed & -0.06 & -0.05 & 0.00 & -0.02 & -0.03 & 0.07 & -0.15 \\
\hline EGP Service Class & 0.14 & -0.05 & -0.02 & -0.01 & 0.11 & -0.07 & 0.14 \\
\hline EGP Intermediate & 0.06 & 0.01 & 0.07 & 0.04 & 0.02 & 0.02 & 0.02 \\
\hline EGP Working class & -0.06 & 0.05 & -0.02 & 0.00 & -0.06 & -0.01 & -0.04 \\
\hline EGP Routine working & -0.10 & 0.03 & 0.01 & -0.04 & -0.11 & 0.03 & -0.07 \\
\hline EGP Self-employed & -0.01 & 0.02 & -0.01 & 0.05 & 0.08 & -0.01 & 0.06 \\
\hline Permanent contract & 0.08 & 0.00 & 0.00 & 0.00 & 0.00 & -0.02 & 0.04 \\
\hline Temporary contract & -0.02 & 0.03 & 0.00 & -0.01 & -0.02 & -0.02 & 0.03 \\
\hline Private sector & 0.10 & -0.02 & 0.02 & 0.00 & 0.05 & 0.01 & 0.03 \\
\hline
\end{tabular}

SOEP 2000-2010, own calculations 
Table 13 Random-effects logistic panel regression predicting further training participation by sex

\begin{tabular}{|c|c|c|c|c|c|c|}
\hline & \multicolumn{2}{|c|}{ Male } & \multicolumn{2}{|c|}{ Female } & \multicolumn{2}{|c|}{ Interaction } \\
\hline & Coeffs. & Odds ratio & Coeffs. & Odds ratio & Coeffs. & Odds ratio \\
\hline Female & & & & & -0.14 & $n s$ \\
\hline Age & $0.11^{* *}$ & $1.12^{* *}$ & 0.05 & $n s$ & $0.08^{* *}$ & $1.09^{* *}$ \\
\hline $\mathrm{Age}^{2}$ & $-0.00^{* * *}$ & $1.00^{* * *}$ & $-0.00^{*}$ & $1.00^{*}$ & $-0.00^{* * *}$ & $1.00^{* * *}$ \\
\hline Married & 0.13 & $n s$ & 0.04 & $n s$ & 0.09 & $n s$ \\
\hline Divorced & 0.12 & $n s$ & 0.18 & ns & 0.14 & $n s$ \\
\hline Children under 16 & 0.06 & $n s$ & -0.10 & $n s$ & 0.00 & $n s$ \\
\hline West & 0.18 & $n s$ & -0.05 & $n s$ & 0.06 & $n s$ \\
\hline Migration & $-0.69^{* * *}$ & $0.50^{* * *}$ & $-0.74^{\star * *}$ & $0.48^{* * *}$ & $-0.72^{* * *}$ & $0.49^{* * *}$ \\
\hline Full-time employment & 0.11 & $n s$ & 0.32 & $n s$ & 0.22 & $n s$ \\
\hline Part-time employment & 0.02 & $n s$ & 0.09 & $n s$ & -0.08 & $n s$ \\
\hline Education intermediate & $0.50^{* * *}$ & $1.64^{* * *}$ & $1.01^{* * *}$ & $2.75^{* * *}$ & $0.71^{* * *}$ & $2.03^{* * *}$ \\
\hline Education high & $0.96^{* * *}$ & $2.61^{* * *}$ & $1.83^{* * *}$ & $6.23^{* * *}$ & $1.37^{* * *}$ & $3.92^{* * *}$ \\
\hline EGP Missing & $0.86^{*}$ & $2.36^{*}$ & 0.19 & $n s$ & $0.49^{*}$ & $1.63^{*}$ \\
\hline EGP Unemployed & 0.53 & $n s$ & $0.91^{* *}$ & $2.48^{* *}$ & $0.76^{* * *}$ & $2.13^{* * *}$ \\
\hline EGP Service class & $1.12^{* * *}$ & $3.08^{* * *}$ & $0.69^{* * *}$ & $1.99^{* * *}$ & $0.90^{* * *}$ & $2.46^{* * *}$ \\
\hline EGP Intermediate & $1.33^{* * *}$ & $3.80^{* * *}$ & $0.77^{* * *}$ & $2.15^{* * *}$ & $1.00^{* * *}$ & $2.72^{* * *}$ \\
\hline EGP Working class & $0.73^{* * *}$ & $2.08^{* * *}$ & 0.06 & $n s$ & $0.45^{* * *}$ & $1.57^{* * *}$ \\
\hline EGP Self-employed & $0.72^{* * *}$ & $2.05^{* * *}$ & 0.10 & $n s$ & $0.43^{* *}$ & $1.53^{* *}$ \\
\hline Permanent contract & 0.23 & $n s$ & $0.32^{*}$ & $1.37^{*}$ & $0.28^{* *}$ & $1.32^{* *}$ \\
\hline Temporary contract & 0.09 & $n s$ & 0.11 & $n s$ & 0.10 & $n s$ \\
\hline Public sector & $0.65^{* * *}$ & $1.92^{* * *}$ & $0.35^{* * *}$ & $1.42^{* * *}$ & $0.49^{* * *}$ & $1.64^{* * *}$ \\
\hline Conscientiousness & -0.09 & $n s$ & 0.01 & $n s$ & -0.06 & $n s$ \\
\hline Agreeableness & -0.13 & ns & -0.01 & $n s$ & -0.13 & ns \\
\hline Extraversion & 0.09 & $n s$ & -0.07 & $n s$ & 0.12 & $n s$ \\
\hline Openness & $0.22^{* *}$ & $1.25^{* *}$ & $0.35^{* * *}$ & $1.42^{* * *}$ & $0.19^{*}$ & $1.21^{*}$ \\
\hline Neuroticism & -0.05 & $n s$ & 0.00 & $n s$ & -0.04 & $n s$ \\
\hline Locus of Control & $0.30^{* * *}$ & $1.34^{* * *}$ & $0.30^{* * *}$ & $1.35^{* * *}$ & $0.29^{* * *}$ & $1.34^{* * *}$ \\
\hline Fem ${ }^{*}$ Conscientious & & & & & 0.06 & $n s$ \\
\hline Fem*Agreeable & & & & & 0.12 & $n s$ \\
\hline FemExtraversion & & & & & $-0.20^{*}$ & $0.82^{*}$ \\
\hline FemOpenness & & & & & 0.19 & $n s$ \\
\hline FemNeuroticism & & & & & 0.04 & $n s$ \\
\hline FemLocus of Control & & & & & 0.01 & $n s$ \\
\hline Constant & $-6.94^{* * *}$ & $0.00^{* * *}$ & $-5.79 * * *$ & $0.00^{* * *}$ & $-6.24^{* * *}$ & $0.00^{* * *}$ \\
\hline $\mathrm{N}$ individuals & 2,460 & & 2,521 & & 4,981 & \\
\hline $\mathrm{N}$ observations & 20,742 & & 19,091 & & 39,833 & \\
\hline AIC & 12,786 & & 11,899 & & 24,706 & \\
\hline Marginal probability & .10 & & .10 & & .10 & \\
\hline
\end{tabular}

Significant at ${ }^{* * *} 0.001{ }^{* *} 0.01 * 0.05$; models control for yearly dummy variables SOEP 2000-2010, own calculations 
Table 14 Sensitivity analysis using alternative model specifications

\begin{tabular}{|c|c|c|c|c|c|c|c|c|c|c|}
\hline & \multicolumn{2}{|c|}{ Original full model } & \multicolumn{2}{|c|}{ Model S1 } & \multicolumn{2}{|c|}{ Model S2 } & \multicolumn{2}{|c|}{ Model S3 } & \multicolumn{2}{|c|}{ Model S4 } \\
\hline & Coeffs. & Odds ratio & Coeffs. & Odds ratio & Coeffs. & Odds ratio & Coeffs. & Odds ratio & Coeffs. & Odds ratio \\
\hline Conscientiousness & -0.03 & $n s$ & -0.03 & $n s$ & -0.05 & $n s$ & -0.11 & $n s$ & -0.05 & $n s$ \\
\hline Agreeableness & -0.08 & ns & -0.07 & $n s$ & -0.06 & $n s$ & -0.07 & ns & $-0.11^{*}$ & $0.90 *$ \\
\hline Extraversion & 0.02 & ns & 0.01 & $n s$ & 0.02 & ns & 0.03 & $n s$ & -0.00 & $n s$ \\
\hline Openness & $0.29 * * *$ & $1.33^{* * *}$ & $0.30 * * *$ & $1.34^{* * *}$ & $0.28 * * *$ & $1.33^{* * *}$ & $0.29^{* * *}$ & $1.34^{* * *}$ & $0.28^{* * *}$ & $1.33^{* * *}$ \\
\hline Neuroticism & -0.02 & $n s$ & -0.01 & $n s$ & -0.01 & ns & -0.03 & $n s$ & -0.02 & $n s$ \\
\hline Locus of Control & $0.30^{* * *}$ & $1.35^{\star * *}$ & $0.30^{* * *}$ & $1.34^{* * *}$ & $0.26^{* * *}$ & $1.30^{* * *}$ & $0.30^{* * *}$ & $1.34^{* * *}$ & $0.31^{* * *}$ & $1.37^{* * *}$ \\
\hline Conscientiousness $^{2}$ & & & & & & & $-0.13^{* *}$ & $0.88^{* *}$ & & \\
\hline Agreeableness $^{2}$ & & & & & & & -0.01 & $n s$ & & \\
\hline Extraversion $^{2}$ & & & & & & & -0.01 & ns & & \\
\hline Openness ${ }^{2}$ & & & & & & & -0.02 & $n s$ & & \\
\hline Neuroticism $^{2}$ & & & & & & & 0.06 & $n s$ & & \\
\hline Locus of Control $^{2}$ & & & & & & & $-0.09^{*}$ & $0.92^{*}$ & & \\
\hline
\end{tabular}

Note: Original full model taken from the main analysis (see Table 8). Sensitivity Model S1 includes control variables for industrial sector and size of company. Model S2 is specified as a hybrid model accounting both for time-varying and time-invariant covariates. Model S3 tests for non-linearity in personality traits. Model S4 tests the original model only on the three waves of the detailed FET module (2000, 2004, and 2008).

SOEP 2000-2010, own calculations 